\title{
The Semiotics of HIV/AIDS Bill-Boards and Their Communication Implications: The Case of Bahir Dar and Gondar Towns in Ethiopia
}

\author{
Cherie Mesfin Gessesse, Bahir Dar University, Ethiopia \\ Lemma Kassaye Sileshi, Bahir Dar University, Ethiopia
}

\begin{abstract}
The study was designed to identify the types of the visual semiotic signs used by different stakeholders who design and prepare billboards on HIV/ADIS to provide mainly the residents of Bahir Dar and Gondar towns with varied information about the epidemic. Besides, it was conducted to tap on the most commonly used visual semiotic signs and the kernel messages represented by these signs during the representational processes of the realities as regards to HIV/AIDS. Consequently, all the 26 HIV/AIDS visual semiotic signs were collected from 22 working billboards that were put up in the main high ways of Bahir Dar and Gondar towns during March, 2011 and analysed qualitatively using Pierce's model. The major results of the study showed that it was wholly the visual iconic signs which were used to represent a range of messages as regards to the HIV/AIDS puzzle unlike the indexical and symbolic signs which were the missed opportunities. There also appeared to be some knowledge gap among stakeholders in HIV/ADIS visual semiotic sign communication systems concerning the actual applications of the visual semiotic signs: indexes and symbols were not considered to transfer the intended messages.
\end{abstract}

Keywords: Communication, Semiotics, Signs, Billboard, HIV/AIDS 


\section{Background of the Study}

Semiotics as a study of visual and symbolic representations of language has been in use in the world when designing, for example, bill boards, advertisements, trademarks, and other forms of signposting we attempt to use to get across our message in all our social practises which require both the elaborated and symbolic functions of languages depending on various factors that will compel us to use either the visual diagrammatic or pictorial representations of language where there may exist an arbitrary, or a direct similarity of representations, or causal relationships between the signifiers and the signifieds or its elaborated forms, i.e., both in spoken and written forms of communications (Chandler, 2007).

From the pre-civilization to the present age, it has become too much customary to experience when human beings use signs for a variety of purposes to achieve a range of goals in education, health, culture, politics and so on endeavors. Like the communication processes in any other endeavors of man, messages about HIV/AIDS have been transmitted to people through both verbal language and visual semiotic signs depending on contexts whereby we employ either verbal signs, or nonverbal, or visual semiotic signs, or both signs systems in combination to construct the reality about the disease. To this end, experience has shown that different individuals, people, and organisations that work on anti-HIV/AIDS programs have been producing myriads of visual semiotic signs in the form of billboards to transfer intended messages about HIV/AIDS.

\section{Statement of the Problem}

In a post modern era, the survival of individuals, selves, groups, institutions, organizations, communities, and countries is largely dependent on the proper and effective use of verbal and nonverbal signs of communications where each plays significant roles in making the intended communication a success. This is not an exception for individuals and organisations that have been working on anti-HIV/AIDS programs, especially those who work on effective use of semiotic signs to unpack the impact HIV/AIDS obviously brings about on the individual, societal, economic, social, political and on other juxtaposition of human endeavors. It appears to in favour of this that Chandler (2005) has forwarded the following. (1) So long as we are always in a state of interaction with the physical reality in our environment, in particular, and the world, in general regardless of where we are and who we are, we cannot let aside the role the visual semiotic signs play in enhancing our communication; (2) It helps 
us challenge the reality how a certain representation, for example, any visual semiotic sign is related to its constructed meaning by way of de-mystifying our understanding about the social realities where, what, how, why we communicate our intentions which are real reflections of those realities which abound our lives; (3) It increases our understanding of the communication processes about how it will be constructed differently depending on the differences existing among ourselves; (4) The understanding of representations and meanings have connection to our intellectual development and a means to an end, where knowledge is constructed depending on our experiences about these visual semiotic signs; (5) Holding back the investigations of signs might be equated with a deliberate manipulation of the development of knowledge, in general, and visual communication in particular regardless of contexts; 6 . The investigations of visual semiotic signs serve as an instrument to develop a relative objective knowledge about those who have been either privileged or suppressed in the representations of the visual semiotic signs.

Viewed from the above argument, the investigations of HIV/AIDS signposts as they have been appeared on the billboards in Bahir Dar and Gondar towns are no more an exception. Above all, even though it has become customary to experience a growing number of visual semiotic signs on HIV/AIDS in Ethiopia in general and in Bahir Dar and Gondar towns in particular, we do not have research evidences on the extent to which do the HIV/AIDS visual semiotic signs are icons, indexes or symbols. The present research is, therefore, an attempt to shade some light on our knowledge of the types and applications of signs, as appeared on HIV/AIDS billboards.

\section{Major Objective of the Present Study}

Bearing those major problems raised in the problem statement section in mind, the study is designed to investigate the application of visual semiotic signs on HIV/AIDS as they have been appeared on the billboards in Bahir Dar and Gondar towns.

\section{Specific Objectives}

By drawing the specific objectives from the major objective of this study, the research has made its entire focus to meet the following specific objectives. Specifically, it is to:

1 Get an understanding of the extent to which the signs are iconic, or indexical, or symbolic;

2 Find out the dominant visual semiotic signs used to address the messages about HIV/AIDS; 
3 Explore how the semiotic messages are communicated through the signs.

\section{Specific Research Questions}

In line with the existing gaps in our understanding of the semiotic signs used on the HIV/AIDS billboards, the following core research questions were framed:

1. To what extent do the HIV/ADIS visual semiotic signs are iconic, indexical, and symbolic?

2. Which of these signs are dominantly applied to represent the intended messages about the social realities of HIV/ADIS?

3. What are the core messages communicated through these visual semiotic signs?

\section{Significance of the Study}

The study is hoped to have manifold advantages to different stakeholders who play significant roles in communicating various messages of HIV/AIDS using visual semiotic signs. Briefly, this study is believed to be significant to:

1 Make aware professions of all levels about the proper applications of visual semiotic signs;

2. Provide research evidence to those concerned authorities of all levels who have been engaged in designing and preparing HIV/AIDS billboards;

3. Make information available to those concerned authorities regarding the types of signs which they have been dominantly employed when representing messages about HIV/AIDS;

4. Present research evidence to people who may have either a direct or indirect connections to the communication processes of messages through designing HIV/AIDS visual semiotic signs;

5. Evaluate as to whether the billboard developers have been applying the visual semiotic signs accordingly;

6. Provide information for the research community as to whether the present status of the social realities of HIV/AIDS has been well-communicated;

7. Provoke research interest among interested professionals on the issue; and

8. Give information to all it may concern about the types and applications of the visual semiotic signs. 


\section{Scope of the Study}

The research examined only the intended meanings of reality as depicted through the visual semiotic signs on the billboards in the two towns from not the viewers of the visual semiotic signs but on the social and personal interpretations of the signs from the researchers' knowledge about the types and applications of visual semiotic signs as deep-rooted in the social, cultural, and personal interpretations of reality regarding the visual semiotic messages as depicted on the bill-boards.

\section{Limitation of the Study}

The study solely depended on the visual semiotic signs, photographs, as they were used as bill-boards as part of the campaign in the fight HIV/AIDS. Though a well-designed two and half pages of questionnaire and an in-depth interview guide were developed to be administered and conducted on different key stakeholders in preparing HIV/AIDS billboards, our attempt remained in vain after two months of uninterrupted trial of lobbying people to fill the questionnaire and being volunteers to be interviewed for mainly many of the staff were away for field work for a long time and lack of interest to take part in the study. Because of these inescapable constraints, the researchers, thus, were forced to solely depend on the analyses of signs, visual semiotic signs.

\section{Research Design and Methodology}

\section{Research Design}

Though the research was initially designed both quantitatively and qualitatively, it was found impossible to continue determinedly with the quantitative design for the two core reasons mentioned in the limitation part of the study. Accordingly, the design of this research remained qualitative throughout.

\section{Research Sites}

Bahir Dar and Gondar towns were selected to be research sites for the study which—all were assumed to be with high population sizes. As a result, these towns were selected for the following couple of reasons.

Firstly, these two towns were too much close to the researchers' work place to use their partime to collect data with frequent visits. Secondly, hence the researchers were on duty 
running their permanent career, classroom teaching, it was too difficult to stay at other towns to collect the required data for it needed repetitive follow-ups.

\section{Research Samples}

This study solely depended on the working HIV/AIDS visual semiotic signs, photographs of real people as appeared on billboards in the main high ways of Bahir Dar and Gondar towns. The samples for the study were the semiotic signs revealed on the billboards which represented different realities about the transmission, prevention, and life of people with HIV/AIDS positive, life of people with HIV/AIDS negative, and messages of people from different walks of life about HIV/AIDS. In brief, the data sources for the study are shown in the following.

Table 1: Samples' Distribution

\begin{tabular}{|c|c|c|c|c|c|}
\hline \multirow[t]{2}{*}{ № } & \multirow[t]{2}{*}{$\begin{array}{l}\text { List of billboards } \\
\text { indicated } \\
\text { Appendixes }(\mathrm{A}-\mathrm{I})\end{array}$} & \multirow{2}{*}{$\begin{array}{l}\text { Town where } \\
\text { the visual } \\
\text { semiotic sign } \\
\text { is found }\end{array}$} & \multirow{2}{*}{$\begin{array}{l}\text { Mode of representation of } \\
\text { reality about HIV/AIDS or } \\
\text { the semiotic sign used to } \\
\text { represent the reality about } \\
\text { HIV/AIDS }\end{array}$} & \multicolumn{2}{|c|}{$\begin{array}{l}\text { Visual Semiotic } \\
\text { Signs as Revealed on } \\
\text { Each Billboard }\end{array}$} \\
\hline & & & & $\mathrm{N}$ & $\%$ \\
\hline 1. & $\begin{array}{l}\text { Billboard } 1 \text { (Appendix } \\
\text { A) }\end{array}$ & Bahir Dar & $\begin{array}{l}\text { Photographs of regional } \\
\text { political leaders }\end{array}$ & 6 & 25.0 \\
\hline 2. & $\begin{array}{llll}\begin{array}{l}\text { Billboards } \\
\text { (Appendix B) }\end{array} & 2 & \& & 3 \\
\end{array}$ & Bahir Dar & $\begin{array}{l}\text { Photographs children Who } \\
\text { lost their parents due to the } \\
\text { disease }\end{array}$ & 2 & 8.3 \\
\hline 3. & $\begin{array}{l}\text { Billboards 4,5, \& } 6 \\
\text { (Appendix C) }\end{array}$ & Bahir Dar & $\begin{array}{l}\text { Photographs of couples who } \\
\text { carried out a volunteer blood } \\
\text { test for HIV }\end{array}$ & 3 & 12.5 \\
\hline 4. & $\begin{array}{l}\text { Billboards 7, 8, 9, \& 10, } \\
\text { (App. D) }\end{array}$ & Bahir Dar & $\begin{array}{l}\text { Photographs of some group of } \\
\text { people with HIV positive }\end{array}$ & 4 & 16.7 \\
\hline 5. & $\begin{array}{l}\text { Billboard } 11 \text { (Appendix } \\
\text { E) }\end{array}$ & Bahir Dar & $\begin{array}{l}\text { Photographs of a family that } \\
\text { did a volunteer blood test for } \\
\text { HIV both before marriage and } \\
\text { delivery of children. }\end{array}$ & 1 & 4.2 \\
\hline 6. & $\begin{array}{l}\text { Billboard } 12 \text { (Appendix } \\
\text { F) }\end{array}$ & Bahir Dar & $\begin{array}{l}\text { A photograph of a person with } \\
\text { HIV positive playing an } \\
\text { activist's role in the fight } \\
\text { HIV/AIDS }\end{array}$ & 1 & 4.2 \\
\hline 7. & $\begin{array}{l}\text { Billboards 13, 14, 15, } \\
\& 16 \text { (Appendix G) }\end{array}$ & Bahir Dar & $\begin{array}{l}\text { Photographs of university } \\
\text { students, and football }\end{array}$ & 5 & 20.8 \\
\hline 8. & $\begin{array}{l}\text { Billboard 17(Appendix } \\
\text { H). }\end{array}$ & Bahir Dar & $\begin{array}{l}\text { A photograph of couples who } \\
\text { are aware of the wise use of } \\
\text { condoms }\end{array}$ & 1 & 4.2 \\
\hline 9. & $\begin{array}{l}\text { Billboard } 18 \text { (Appendix } \\
\text { I) }\end{array}$ & Bahir Dar & $\begin{array}{l}\text { Photographs of religious } \\
\text { leaders and people with HIV } \\
\text { positive. }\end{array}$ & 1 & 4.2 \\
\hline \multicolumn{4}{|c|}{ Total number of visual semiotic signs in Bahir Dar } & 24 & 100.0 \\
\hline 10. & $\begin{array}{l}\text { Billboard } 19 \text { (Appendix } \\
\text { G) }\end{array}$ & Gondar & $\begin{array}{l}\text { Photographs of university } \\
\text { graduates and their disabled } \\
\text { colleagues. }\end{array}$ & 1 & 50.0 \\
\hline
\end{tabular}




\begin{tabular}{|l|l|l|l|l|l|}
\hline 11. & Billboard 20 (Appendix & Gondar & $\begin{array}{l}\text { Photographs of religious } \\
\text { leaders, community leaders } \\
\text { and persons with HIV } \\
\text { positive. }\end{array}$ & 1 & 50.0 \\
\hline
\end{tabular}

\section{Sampling Techniques}

All the working visual semiotic signs as they were appeared on HIV/AIDS billboards in the major high ways of Bahir Dar and Gondar towns were photographed and selected purposively. This was done with intentions; for one thing, it was assumed that taking all the visual semiotic signs on all these billboards would give a much wider picture of the types and applications of visual semiotic signs. For another, it would also provide greater opportunities to identify the genres of messages represented through these visuals semiotic signs that were frequently used in the promotion and communication of HIV/AIDS epidemic to people.

\section{Variables}

The most common related variables to the specific objectives in this research were visual semiotic signs per se. The classification of the visual signs was used with the following brief description as revealed below:

$>$ Iconic signs - refer to a mode in which reality about HIV/AIDS is revealed through the visual semiotic signs per se and communicated by people as the signifier is perceived as resembling the signified such as recognizably looking, sounding, feeling, the latter (Chandler, 2007)

$>$ Indexical signs - represent a mode in which the signifier is not purely arbitrary but is directly connected in some way, example, through physically or causally relationships to its signified form (Chandler, 2007).

$>$ Symbolic signs depict a mode in which the signifier does not resemble the signified, but which is arbitrary or purely conventional (Chandler, 2007).

\section{Method of Data Analyses}

Semiotic qualitative research analyses were used where the representations of the social reality of HIV/AIDS were examined from the linguistic perspectives of the visuals semiotic signs, how meaning would be constructed from the triadic model of signifier, signified, and 
interpretant. That is to say, the personal, social, political, economic, and health constructions of realities about HIV/AIDS were made from these visual semiotic signs.

The analyses of the visual semiotic signs regarding the messages of HIV/AIDS heavily depended on Peirce's triadic sign relationships model given below in figure 1.

Representamen (Saussure's Signifier, Designated by X referring to the conceptual part referring to the object, such as words, images, sound, gesture and so on. E.g., the photographed photos (iconic signs) of different personalities as shown on the different billboards, See the Appendices A to M).

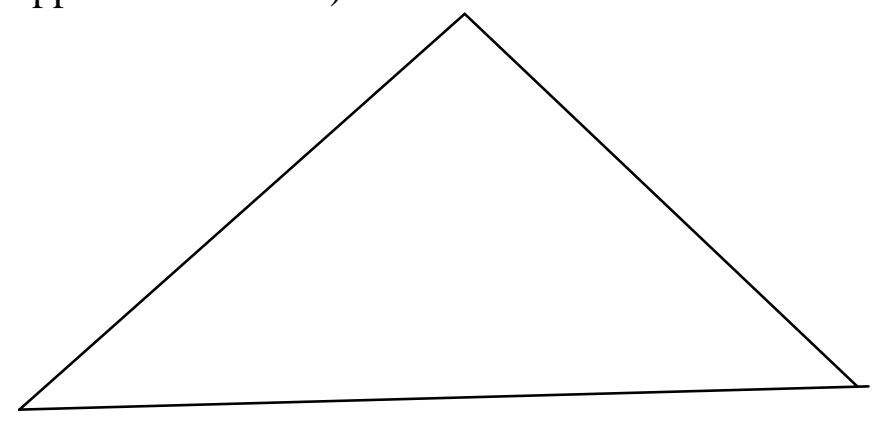

Object (Saussure's Signified, Designated by Y concept, i.e., the physical part of the object. E, g., by the sign, the physical features of those photographed interpreter persons or personalities as appeared on the billboards.) signifier
Interpretant (the mental image, or evoked in an interpreter's mind as Saussure termed it, when the constructs meaning from the interplay between the representamen or and objects or the signified.)

Fig1. The Triadic Peirce's Sign Theory, Model (Danesi, 2004:26).

(Reminder: The notes given in parentheses are the researchers' own illustrations).

Accordingly, all visual semiotic signs or photographs of people on all the collected billboards in the main highways of the two towns were categorised based on the content similarity of the messages about HIV/AIDS. For the sake of convenience and reduction of data, thus, a photographically revealed messages of some of the regional political leaders and figures, children who lost their parents due to HIV/AIDS, couples who carried out a volunteer blood 
test for HIV/AIDS before and after marriage, the life of couples after a volunteer blood test for HIV/AIDS, committed couples who did a volunteer blood test for HIV/AIDS, a person's message how difficult it was to identify people who were HIV positive from who were not by sight, long run goals of university students and football players, partners' wise use of condoms, and religious fathers and public figures were primarily used as the major patterns to classify semiotic signs on those 20 billboards containing a range of messages about HIV/AIDS.

Consequently, the collected visual semiotic signs were categorised as either icons, or indexes, or symbols in line with the specific properties of each visual semiotic sign. Once the genre of each photograph or visual semiotic sign was identified, the types of the signs used to address a range of messages as regards to HIV/AIDS through the photographically addressed signs were also computed by counting the frequency of the specific signs as it occurred in the list. Besides, analyses of captioned messages or the mottos of those photographically appeared personalities were also analysed in relation with the implications of the underlined intended and perceived meanings of the employed visual semiotic signs in qualitative terms.

\section{Results and Analyses}

Guided by the research questions set, any resulting data was analysed and discussed accordingly. As regards to the first research question, the extent to which the semiotic signs were icons, or indexes, or symbols, the analyses was made based on those 26 working semiotic signs as contained on those 20 billboards. Of which 18 of them contained 24 visual semiotic signs which were found in Bahir Dar town whereas 2 of the billboards with 2 visual semiotic signs were put up in Gondar town. 
Table 2: List of Billboards, the Visual Semiotic Signs Used to Represent the Reality about HIV/AIDS, the Genres of the Visual Semiotic Signs, and the Frequency and Percentage of Each Genre.

\begin{tabular}{|c|c|c|c|c|c|}
\hline \multirow[b]{2}{*}{ 이 } & \multirow[t]{2}{*}{ 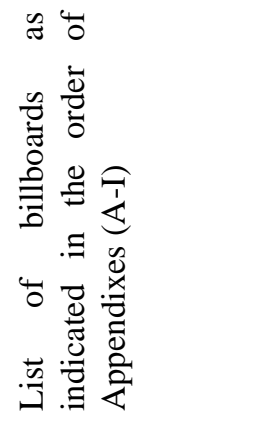 } & \multirow[t]{2}{*}{ 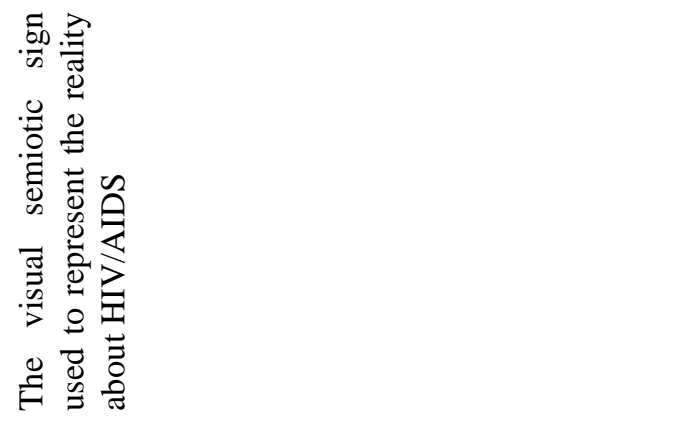 } & \multirow[t]{2}{*}{ 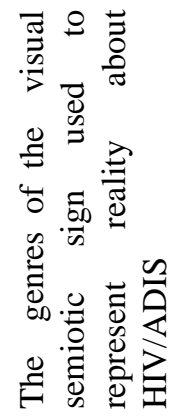 } & \multicolumn{2}{|c|}{ 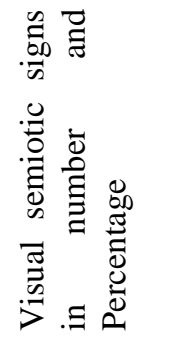 } \\
\hline & & & & Z & $\delta^{\circ}$ \\
\hline 1. & Billboard 1 & Photographs of regional political leaders & Icons & 6 & 25.0 \\
\hline 2. & Billboards $2 \& 3$ & $\begin{array}{l}\text { Photographs of children Who lost their parents } \\
\text { due to the disease }\end{array}$ & Icons & 2 & 8.3 \\
\hline 3. & $\begin{array}{l}\text { Billboards } 4,5, \& \\
6\end{array}$ & $\begin{array}{l}\text { Photographs of couples who carried out a } \\
\text { volunteer blood test for HIV/AIDS }\end{array}$ & Icons & 3 & 12.5 \\
\hline 4. & $\begin{array}{l}\text { Billboards 7, 8, 9, } \\
\& 10\end{array}$ & Photographs of people with HIV positive & Icons & 4 & 16.7 \\
\hline 5. & Billboard 11 & $\begin{array}{l}\text { Photographs of a family that did a volunteer } \\
\text { blood test for HIV/AIDS both before marriage } \\
\text { and delivery of children. }\end{array}$ & Icons & 1 & 4.2 \\
\hline 6. & Billboard 12 & $\begin{array}{l}\text { A photograph of a person with HIV positive } \\
\text { that seem to playing an activist's role in the } \\
\text { fight HIV/AIDS }\end{array}$ & Icons & 1 & 4.2 \\
\hline 7. & $\begin{array}{l}\text { Billboards } 13,14, \\
15, \& 16\end{array}$ & $\begin{array}{l}\text { Photographs of university students and } \\
\text { footballers }\end{array}$ & Icons & 5 & 20.8 \\
\hline 8. & Billboard 17 & $\begin{array}{l}\text { A photograph of couples who were aware of } \\
\text { the wise use of condoms }\end{array}$ & Icons & 1 & 4.2 \\
\hline 9. & Billboard 18 & $\begin{array}{l}\text { Photograph of religious leaders and people } \\
\text { with HIV positive. }\end{array}$ & Icons & 1 & 4.2 \\
\hline Tot & number and percents & of the visual semiotic signs in Bahir Dar & & 22 & $\begin{array}{l}100 . \\
0\end{array}$ \\
\hline 11. & Billboard 19 & $\begin{array}{l}\text { Photographs of university graduates and } \\
\text { colleagues. }\end{array}$ & heir disabled & $\mathrm{I}$ & 50.0 \\
\hline 12. & Billboard 20 & $\begin{array}{l}\text { Photographs of religious leaders, community } \\
\text { persons with HIV positive. }\end{array}$ & leaders and & $\begin{array}{l}\mathrm{I} \\
\mathrm{c}\end{array}$ & 50.0 \\
\hline
\end{tabular}




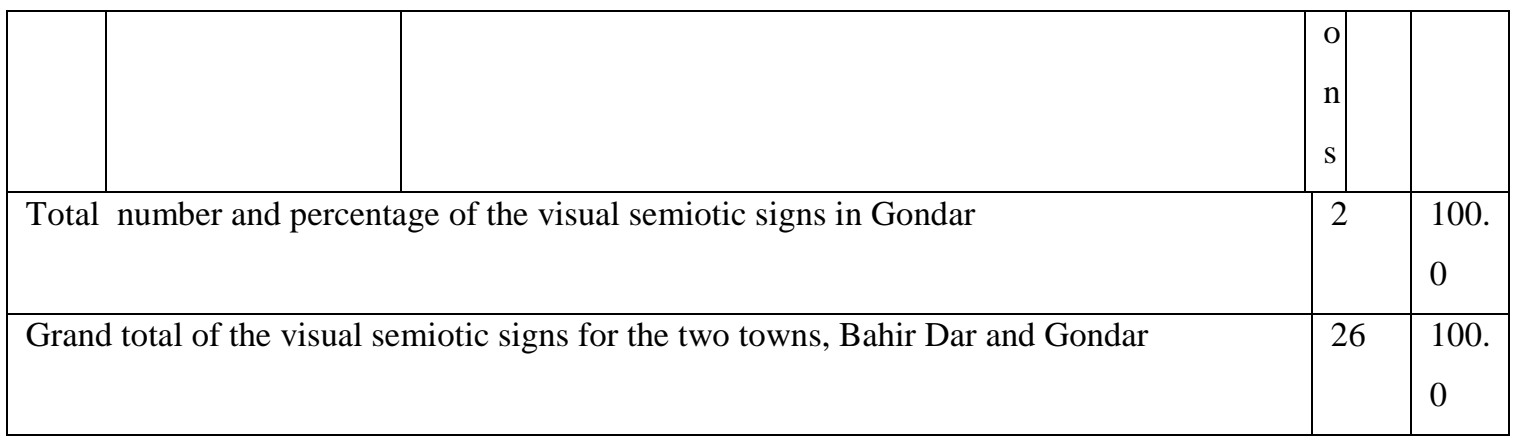

Basically, as illustrated above in Table 2, all of the visual semiotic signs, irrespective of the observed differences among the photographs of the actual people which tended to include people from different walks of life, all the messages, as represented via the 26 (100 percent) visual semiotic signs, were iconically signaled or icons.

On the one hand, these visual semiotic signs (photographs) were mere reproductions of actually existing people in the towns or the signs signified a relationship between the signified (actual existing people) and the signifier (their photographs).The representation of reality about HIV/AIDS was made out of the existed relationships between the signifieds and the signifiers. This identification of visual semiotic signs appeared to support Sebeok's view (2001:10): “An icon is a sign that is made to resemble, stimulate, or reproduce its referent in some way. Photographs may be iconic signs because they can be seen to reproduce their referents in a visual way."

These visual semiotic signs, on the other hand, used to represent the multifaceted realities, such as social, individual, health, societal, political, economic, and concomitant realities about HIV/AIDS in both towns were entirely icons regardless of the disparities observed in the number of samples in these towns. Index and symbol visual semiotic signs, on the other hand, were not used to communicate a range of messages to the people in these towns. As a result, we learned that nominating these non existed visual semiotic signs, i.e., indexical and symbolic signs with zero value was a waste of time and would become awkward so long as they were not used in the representational system of the truth about HIV/AIDS.

At a secondary level, a semiotican would disagree with the above finding if he/she understood the value of photographs in such a way that these signals had various facets where 
all the photographs indicated the people actually exist. Consequently, the signs which were iconic at a primary level could become indexical visual semiotic signs at a secondary level.

Stakeholders who were engaged in designing and preparing the visual semiotic signs on the billboards played leading roles in the fight against HIV/AIDS transmission and would implicate two basic issues in communicating the existing realities to people as regards to the HIV/AIDS epidemic.

Firstly, this finding indicted that iconic representation techniques tended to exist in abundance in human experience in the fight against the spread of HIV/AIDS, despite the fact that it was not clear to us why did the designers and developers of HIV/AIDS visual semiotic signs merely depend on these signs. Goes with this, Danesi (2004:28) stipulates: "Iconicity abounds in all domains of human representation."

Secondly, the finding of this study tended to contradict with Moriarty and Shay's law of representational transparency, as appeared in Smith et al (2005) which made it evident that indexical signaling systems were more transparent than the other two representational systems which were not at all reported as visual semiotic representation systems. The study also seemed to implicate that the iconically signaled semiotic signs would make the interpretation of meaning somehow more difficult as it was the case in indexical signaling systems unlike the symbolic representational codes where it was reported that there did not exist physical intervention of the referents as they stood for people, animals, and incidents during the meaning construction processes.

As regards to the second research question, the extent to which of the visual semiotic signs were dominantly in use, all the visual semiotic signs were icons and none of the semiotic signs was indexes and symbols; it was the iconical visual semiotic representations that were exclusively used in transferring a range of messages as regards to the HIV/AIDS epidemic though the exclusive dependence of the stakeholders on iconic signs would implicate other qualitative research as to why did these people become wholly dependent on these signs.

What were the visual semiotic messages communicated through the signs was the question that formed the third research question. Accordingly, the semiotic messages are discussed in 
relation to the personal, cultural, social, political, economic, societal, health and so on implications of the photographs and the Amharic (language of wider communication in Ethiopia) captioned captions found on those visual semiotic signs. Thus, a brief description of each visual semiotic sign, its function, the mediated interpretations of each visual semiotic sign, photograph, the Amharic captioned caption of each sign as translated into English, the frequency, and percentages of the iconically signaled visual semiotic signs are portrayed in Table 3 below.

To begin with, all the visual signs were used as models, as shown in Table 3, to provide multifaceted information on HIV/AIDS epidemic. Consequently, the whole analyses and discussions were dependent on all these 24 semiotic signs found in Bahir Dar and two other visual semiotic signs found in Gondar which had content similarities with those found in the former town, except, there were minor differences made on the visual semiotic signs.

Table 3: Genres of Visual Semiotic Signs, their Functions, and Kernel Realities Represented with the Signs, Captioned Messages, and the Frequencies and Percentages of the Signs.

\begin{tabular}{|c|c|c|c|c|c|c|}
\hline \multirow[b]{2}{*}{$z_{1}^{\prime}$} & \multirow{2}{*}{ 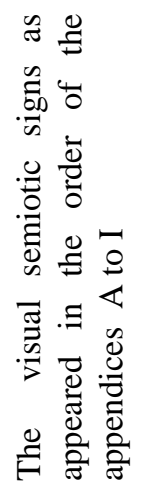 } & \multirow{2}{*}{ 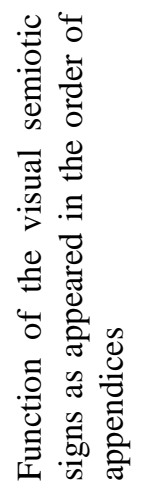 } & \multirow{2}{*}{ 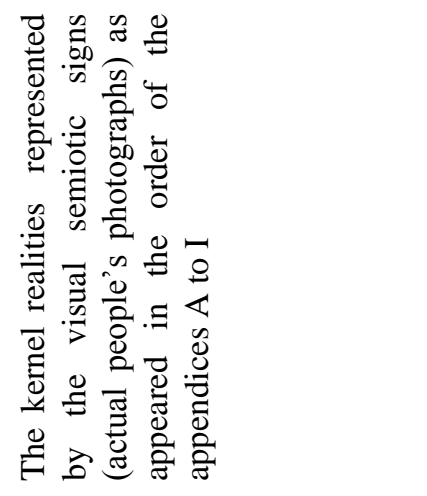 } & \multirow{2}{*}{ 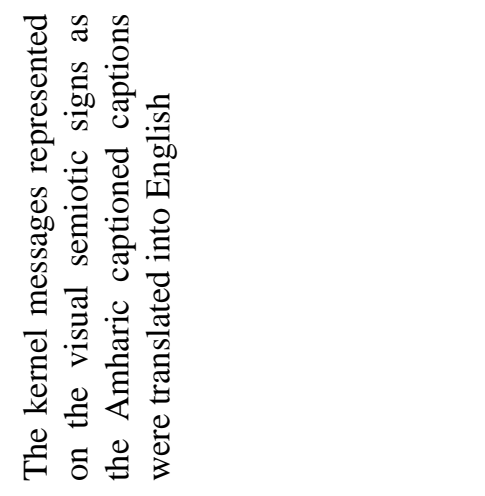 } & \multicolumn{2}{|c|}{ 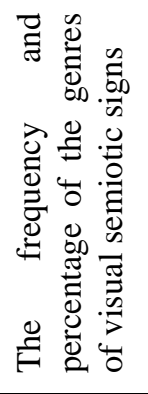 } \\
\hline & & & & & z & $\delta^{\circ}$ \\
\hline 1. & Icons & Modeling & $\begin{array}{l}\text { Playing } \begin{array}{l}\text { leading, } \\
\text { (change }\end{array} \\
\text { revolutionary } \\
\text { agents) pioneering roles in } \\
\text { the fight against the spread } \\
\text { of HIV/AIDS perhaps as } \\
\text { they did it in politics. }\end{array}$ & $\begin{array}{l}\text { "Those who love their followers } \\
\text { should be pioneers in the fight } \\
\text { against HIV/AIDS!" }\end{array}$ & 6 & 25.0 \\
\hline 2. & Icons & Modeling & $\begin{array}{l}\text { Standing by the side of } \\
\text { children who lost their } \\
\text { families due to HIV/AIDS. }\end{array}$ & $\begin{array}{l}\text { "Do not turn your back!" "Let } \\
\text { us fight HIV/AIDS!" Let us live } \\
\text { for our words!" "Now, we do } \\
\text { not say that we have no } \\
\text { families!" and "Our hope is } \\
\text { blossoming!" }\end{array}$ & 2 & 8.3 \\
\hline 3. & Icons & Modeling & $\begin{array}{l}\text { Couples who tested their } \\
\text { blood for HIV/AIDS called } \\
\text { for others to follow their } \\
\text { footsteps. }\end{array}$ & $\begin{array}{l}\text { "We did blood test for HIV } \\
\text { before our marriage!" "The } \\
\text { couples who trusted each other } \\
\text { without blood test for HIV were } \\
\text { equated with a life over steep }\end{array}$ & 3 & 12.5 \\
\hline
\end{tabular}




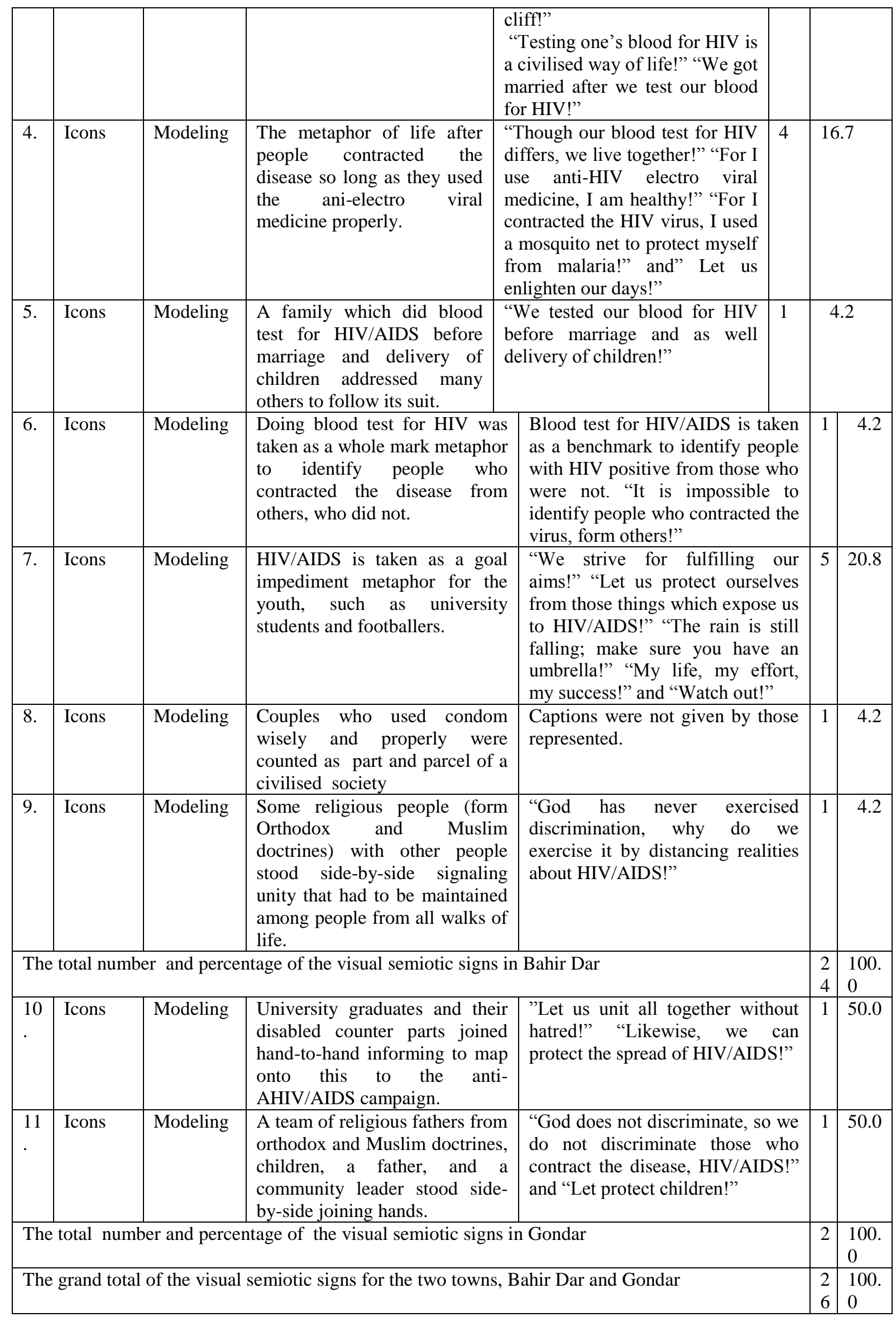


These politically loaded visual semiotic signs appeared to serve as a tool of change in fighting against HIV/AIDS epidemic; hence, it would bring some synergy in the mind of people who did not test their blood for HIV/AIDS, on one way or the other. It also seemed to carry a message of political revolution which took place, perhaps, in the system so that people of the town would model the messages represented by the visual semiotic signs to bring some kind of revolutionary change in their knowledge, skills, and attitude or behaviour about HIV/AIDS. Above all, as politics and revolution could be taken as faces of a coin; this meaning would go with the idea of bringing revolutionary change in the anti-HIV/AIDS campaign at large. This conception was also confirmed by the captioned messages of these 6 regional political leaders which were originally written in Amharic (Appendix A for the Amharic version) and were translated into their English version as: "Those who love their followers should be pioneers in the fight against HIV/AIDS."

University students' and footballers' goals (21 percent) and people's life after they contracted HIV/AIDS (17 percent) were the second and third highest visual semiotic iconic signs used, respectively to give out a wide range of information to people of Bahir Dar and Gondar towns regarding the disease, HIV/AIDS.

Presumably, the representations of the reality about HIV/AIDS, through these iconically signaled visual semeiotic messages via photographs of university students and other footballers tended to help the rest of youth of Bahir Dar town to model the message for the representation mechanism was addressed probably via the photographs of their age mates than it would be otherwise. Because it would be argued that the more people tended to have much proximity in terms of many sociolinguistic variable, such as age, way of dressing, language, common goals and so on with people who were represented by the iconic semiotic signs (photographs), it is likely that the messages would give sense to who they refer to. Though these semiotically represented visual messages on HIV/AIDS appeared to be inclusive, the information represented through the photographs of university students and footballer seemed to have much more direct implications to the wider youth.

Despite this, it was still a small figure for three reasons. For one thing, compared to its actual size where it is usually believed to constitute the majority of the total population of developing countries like Ethiopia where Bahir Dar and Gondar would not be exceptions, it 
would be taken as insignificant number. For another, it would be axiomatically argued that this section of the population could be taken as a sexually active group of the population and is usually taken as the section of the population that had to shoulder a lot of responsibilities.

All the messages represented through the visual semiotic signs of the youth's photographs would help the other people to construct realities by modeling what was transmitted by the semiotic signs unlike the politically loaded messages that came from the top to address people downward in the hierarchy which is a common experience to the people as the day in and out.

Just like the percentage of the semiotic signs of the youth, the percentage of the visual semiotic signs of people who contracted the disease was too small as compared to the political figures; hence it was nearly 17 percent. Realities constructed from these visual semiotic signs were likely to be different from other visual semiotic signs in many perspectives. Primarily, the billboard makers exclusively depended on these semiotic signs for they were to reveal much lived experiences and practises about the disease. As a result, people who would construct messages from these visual semiotic signs were likely to gain much information about the HIV puzzle. Also, these semiotic signs might ask people to stop for a while and take actions which would range from testing one's blood for HIV to other next steps that would require thoughtful decisions in change of behavior.

The other visual semiotic iconic signs, photographs, were used to represent the "truth" about HIV/AIDS were the photographs of three couples that constituted nearly 13 percent of the total of the iconic signs. The core message contained on these semiotic signs was a call for blood test for HIV. And it would serve as a "rule of thumb" among any expected couples to carry out blood test for HIV before marriage. It was educative to use the couples in the representation processes of the reality about HIV/AIDS, for one thing, they constituted some form of the larger society in Bahir Dar and Gondar, and for another, these representation techniques would serve as a bridge for people who decided to pass to the next line of human life, marriage-hood. This idea was also made metaphorically as the Amharic captioned captions were translated into English. The couples who trusted each other without blood test for HIV were equated with a life over steep cliff. Thus, the message was clear and direct. 
The last group of people used in the visual semiotic sign representations of the reality regarding HIV/AIDS were orphans, a family which did blood test for HIV before marriage and delivery of children, a person's advice how difficult it was to identify people who contracted the disease from others, couples who used condom wisely and properly in the society, and some religious people (from Orthodox and Muslim doctrines) along with community members and community leaders with percentages of 8.3, 4.2, 4.2, 4.2, 4.2, respectively. This was to say, the photograph of each of these groups of people were used as an iconic visual semiotic sign below ten percent which was too small compared to the iconic signs of political leaders, the youth, people who contracted the disease, and as well the couples. These representations of realities about HIV/AIDS tended to contradict with the existed social realities among the town dwellers for the following basic reasons.

Firstly, it was evident from both daily print and broadcast media of the Amhara region that there were many children who lost their parents. Consequently, this would, in turn, invite the use of children's photographs as iconic visual semiotic signs to represent the reality to the population of Bahir Dar.

Secondly, experience made it clear that many of the people in the towns were reported to be from either the Christians or Muslims doctrines, or other religions which were being practised by other sector of the population. Thus, this small figure, i.e., 4.2 percent of religious leaders' photographs was used which tended to fail to recognise this reality. Rather, religious leaders and community activists could have been given more representations that would help the stakeholders transfer the intended messages via these visual signs. The question to be posed was that how could people construct meanings from these visual semiotic signs where there existed a range of such variables. In general, all the visual semiotic iconic signs used in the representations of the different realities about the disease, HIV/AIDS, tended to fail to:

Meet the social structure of people where, in real life, there existed many disparities;

$>$ Give a relatively equal representations to people from all walks of life;

$>$ Recognise the age aggregations of people, for example, a semiotic visual sign that was put up to school children had to resemble to those children in many perspectives;

$>$ Apply the most commonly used language in the towns when the captions were written; 
$>$ Provide a relatively faire representations and explanations about people's religion; and

$>$ Present knowledge, skills, and attitudes through a variety of dominant multimodal visual semiotic sign representation techniques.

\section{Conclusion and Recommendations}

\section{Conclusion}

Concomitant with the discussions and the findings that were made in the previous sections of this report, the following conclusions were made. It was made evident that the visual iconic semiotic signs were used as the only modes of representations of the realities about HIV/AIDS in both towns, Bahir Dar and Gondar.

Despite this, the findings would raise core questions about the gaps existed as regards to the knowledge and skills of the governmental and nongovernmental organisations concerning the applications of varieties of visual semiotic signs so as to transfer a range of intended messages.

Since it was wholly the visual iconic semiotic signs that were dominantly used to transfer the intended messages of stakeholders to the dwellers of the towns, viewers tended to pay less attention for the these messages represented by the visual iconic representation. This would, in turn, question as to whether the messages were addressed to the people to bring the intended effect, change in behavior as regards to the HIV/AIDS epidemic for it is typically similar to their daily routines.

Even within the visual iconic semiotic sign representations, there were many disparities. For example, it was the photographs of the politicians that were the highest recurred visual semiotic signs, i.e., 25 percent unlike religious leaders and community leaders, i.e., 4.2 percent who believed to have much more acceptance by the people to whom the semiotic signs were meant for. In addition, the visual iconic semiotic signs did not give fair representations to people from different walks of life such as children, youth, adult, and elders. 
In general, the findings showed that the visual iconic semiotic signs did not recognize many sociolinguistic variables that made classifications among the society, such as common language, age, gender, social classes, education, and occupations.

\section{Recommendations}

The following were appeared in the recommendation of the present study to positively affect people's attitude, behavior, and practises as regards to the messages conveyed by the visual iconic semiotic signs.

Stakeholders in anti-HIV/AIDS campaigns need to have a shared understanding when they design and prepare visual semiotic signs to better represent messages through these representation modalities; The concerned authorities should better represent messages about HIV/AIDS via different visual semiotic signs. When the messages represented through these visual semiotic signs, they should reflect the objective realities that exist on the ground, such as, age, gender, language, occupations, social classes, and level of literacy of the signified;

Varied levels of trainings should be designed where all stakeholders in HIV/AIDS visual semiotic signs will get insights to develop their knowledge and as well as build their skills about the effective applications of the visual semiotic signs; Impact assessment on the effectivenesses of the representation of messages through visual semiotic signs should be carried out on stakeholders.

Other studies with large samples should be carried out on the effective applications of human communications and the types of HIV/AIDS messages conveyed as the result of these communication channels, visual semiotic signs. 


\section{References}

Bloomer, et al. (2005). Introducing Language in Use: A Coursebook. London and New York: Routledge, Taylor and Francis Group. [ Book 95)

Bringham, L. (2002). Decoding Visual Language Elements in News Content. Available at www.katebrigham.com/thesis.

Chandler, D. (2007). Semeiotics: the Basics. London and New York: Routledge, Taylor and Francis group.

Cobley, P. (ed.). (2001). The Routledge Companion to Semiotics and Linguistics. London and New York: Routledge, Taylor and Francis Group.

Danesi, M.(2004). Messages Signs, and Meanings: A Basic Textbook in Semiotics and Communication. $3^{\text {rd }}$ Edition. Canada, Toronto, Canadian Scholars' Press Inc.

Free, D., \& Inwood, B. (2005). Introduction. In D. Frede \& B. Inwood.(eds.). Language Learning: Philosophy of Language in the Hellenistic Age. Cambridge: Cambridge University Press.

Jamieson, H. (2007). Visual Communication: More than Meets the Eye. Bristol, UK, Intellect Ltd.

Moriarty, A. (2005). Visual Semiotics. In Smith et al.'s (eds.). Handbook of Visual

Communication: Theory, Methods, Media. Mah Wah, New Jersey: Lawrence Erlbaum Associates, Publishers.

Moriarty A. and Sayre S. (2005). An Intended-Perceived Study Using Visual Semiotics. In Smith et al.'s (eds.). Handbook of Visual Communication: Theory, Methods, Media. Mah Wah, New Jersey: Lawrence Erlbaum Associates, Publishers.

Sebeok, T. A. (2001). Signs: An introduction to Semiotics. $2^{\text {nd }}$ Edition. Toronto: University of Toronto Press.

Smith, et al.(2005). Handbook of Visual Communication: Theory, Methods, Media. MahWah, New Jersey: Lawrence Erlbaum Associates, Publishers.

Stam, et al. (2005). New Vocabularies in Film Semiotics: Structuralism, Post-Structuralism and Beyond. $6^{\text {th }}$ Edition. London and New: Routledge

Trifonas, P. P. (2001). Post Modern Encounters: Barthes and Empire of Signs. UK. Duxford, Cambridge, Icon Books Ltd. 
Appendix A: Billboards depicting the photograph of some of the major regional political leaders as they were doing a volunteer HIV blood test
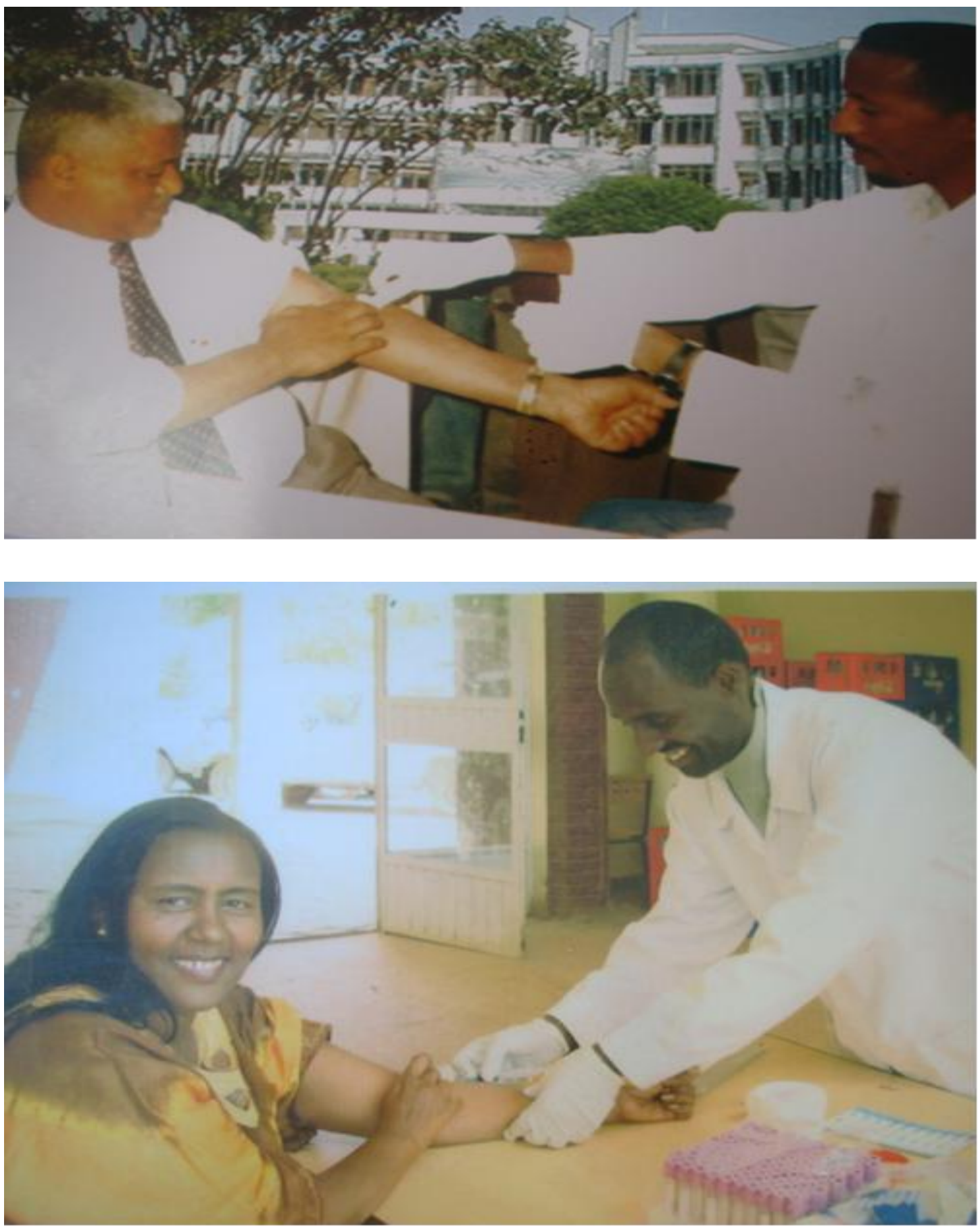
Volume: 3 - Issue: 1 - January - 2013
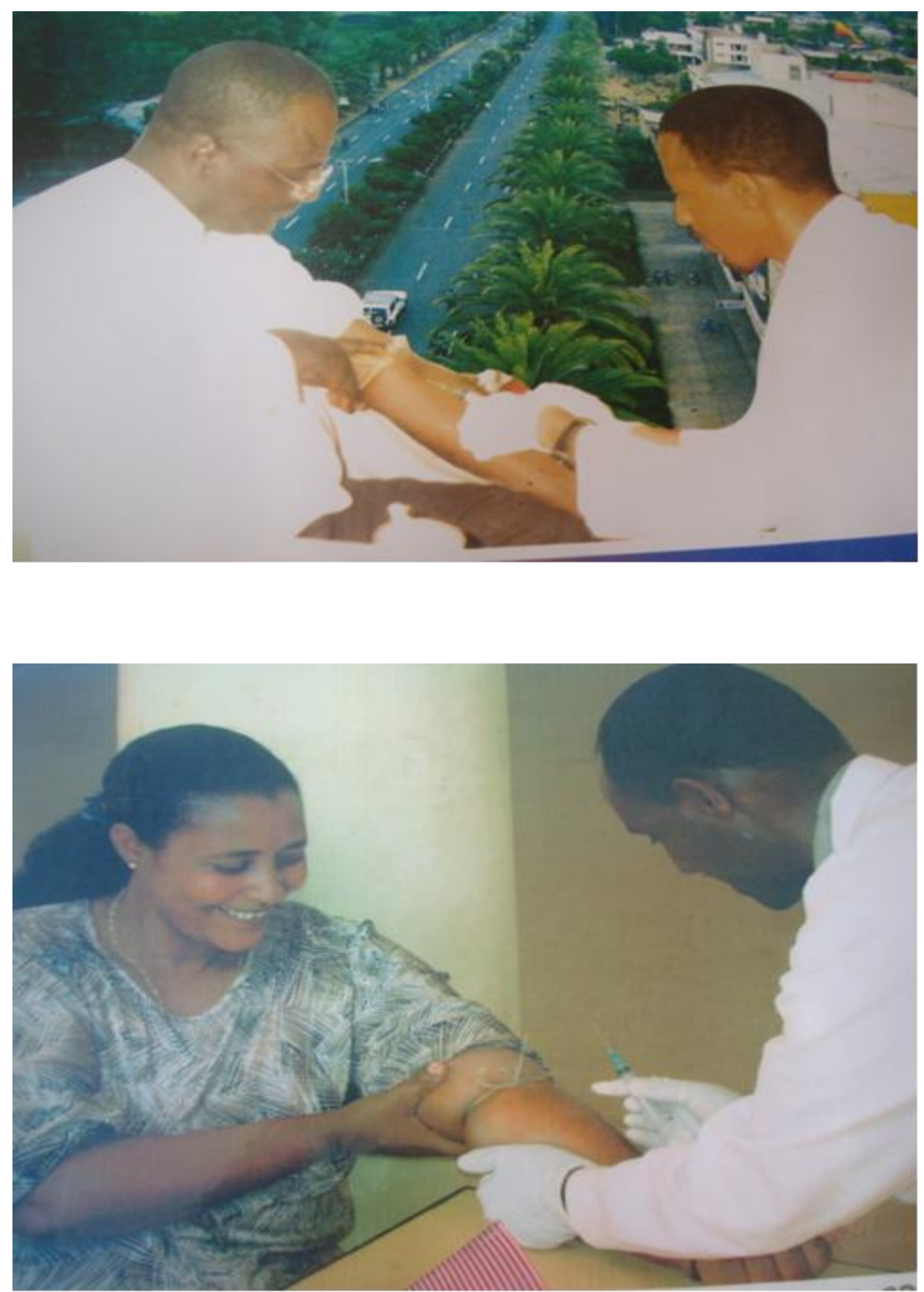

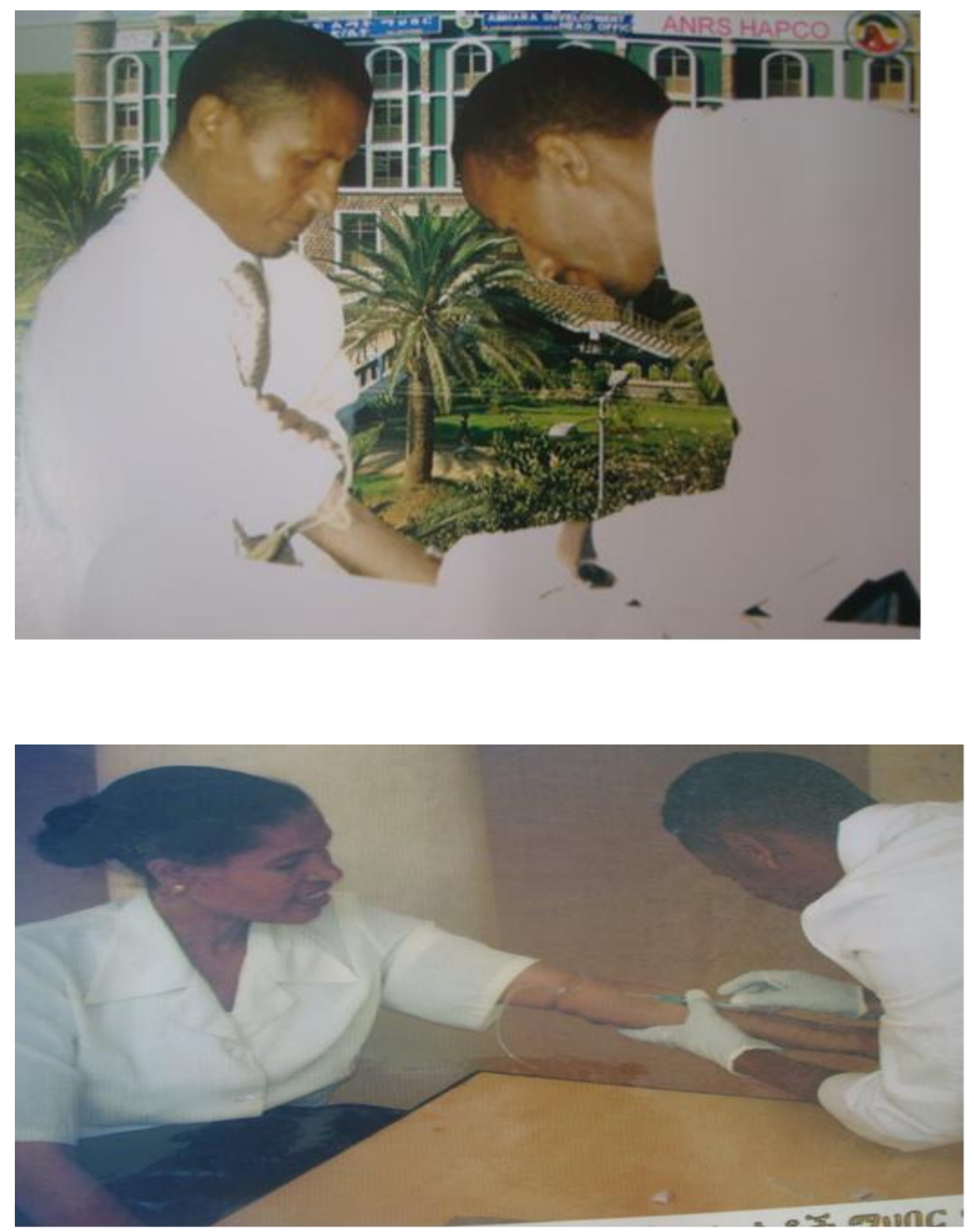
$j\left(m T_{T}\right.$

Appendix B: Billboards Depicting Orphan's Hopes Who Lost their Parents Due to HIV/AIDS
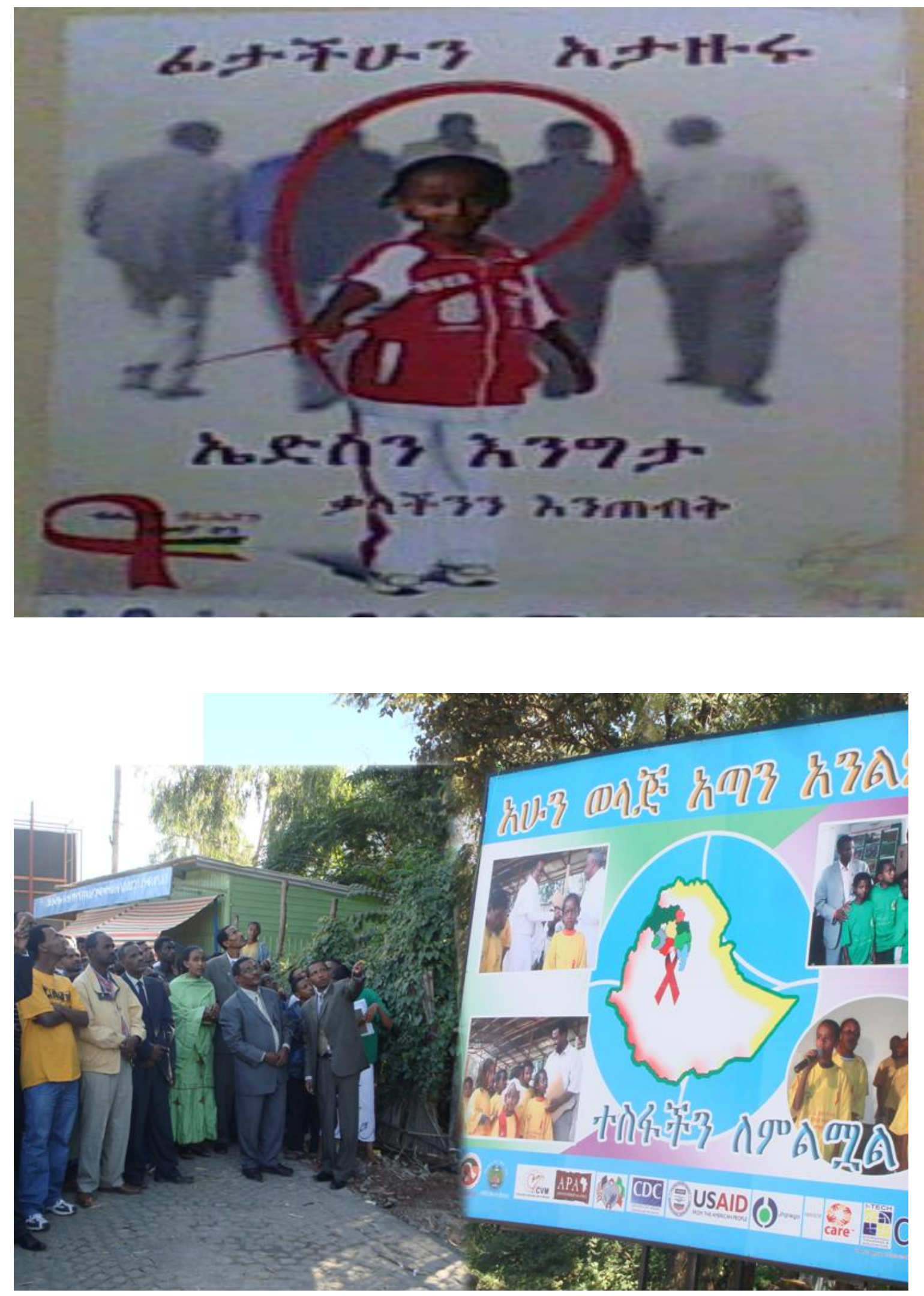
Appendix C: Couples who carried out a Volunteer Blood Test before Marriage for HIV
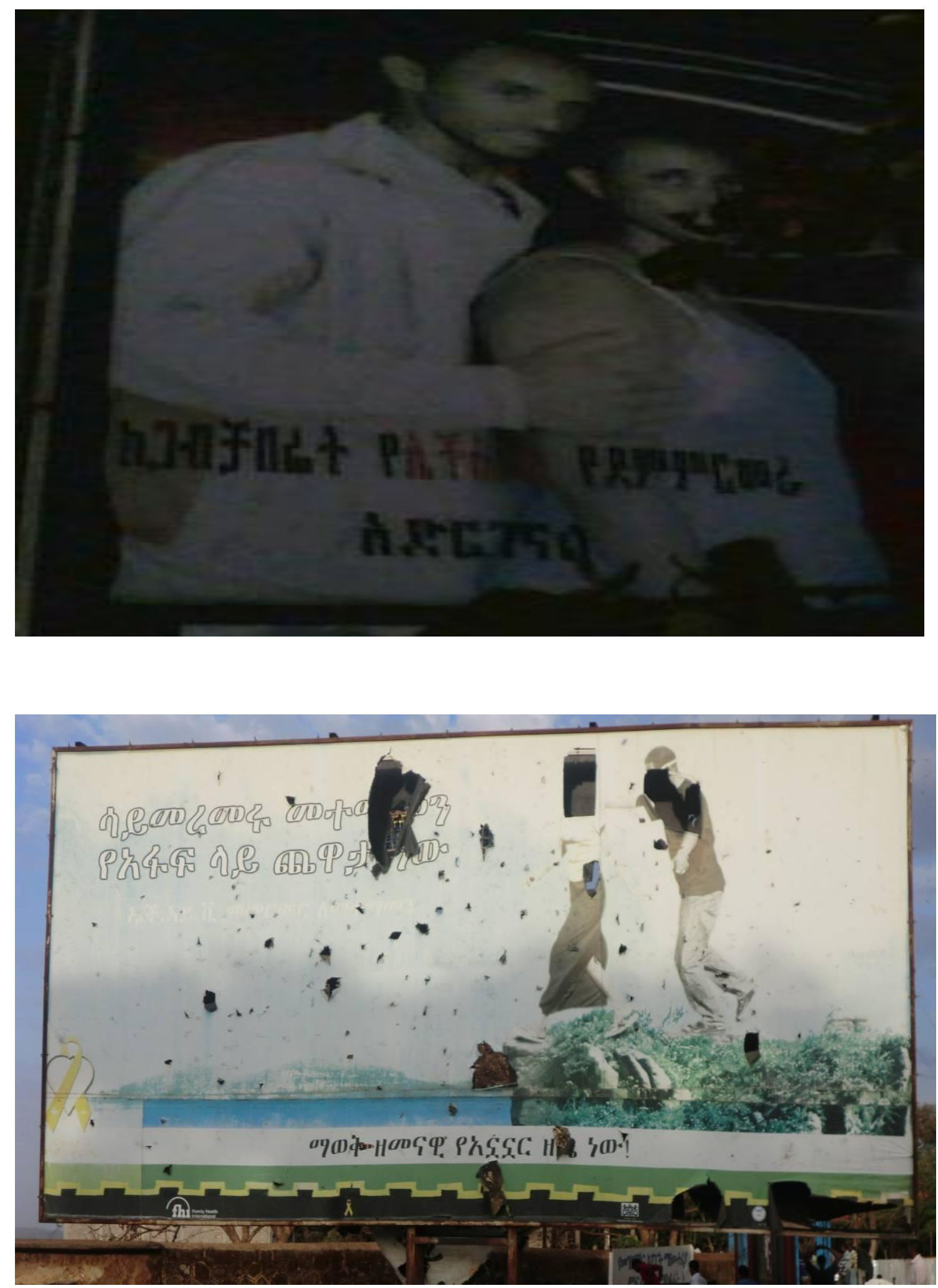


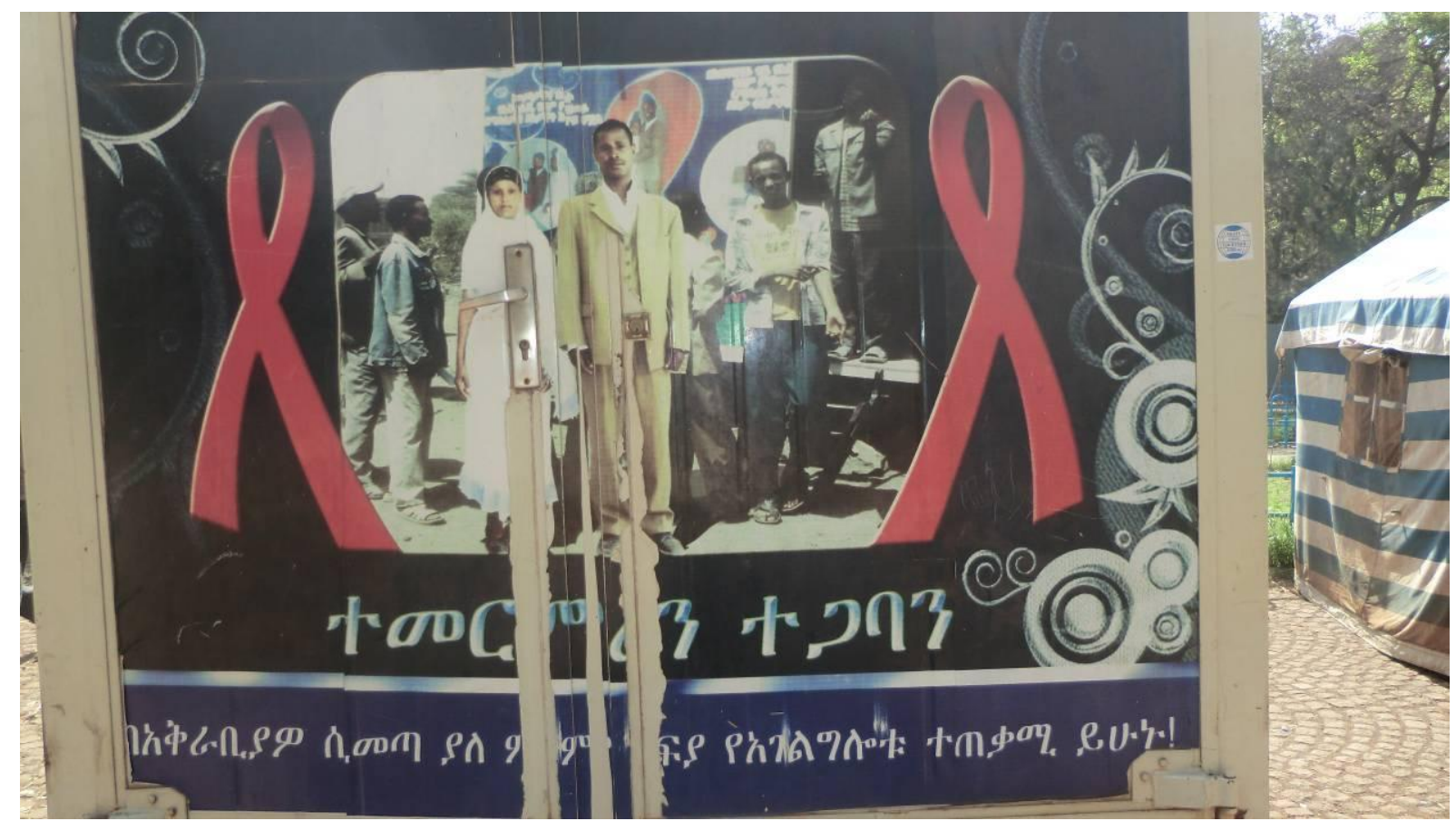


$j\left(m_{T}\right.$

Appendix D: Billboard Depicting the Photographs of People with HIV Positive.
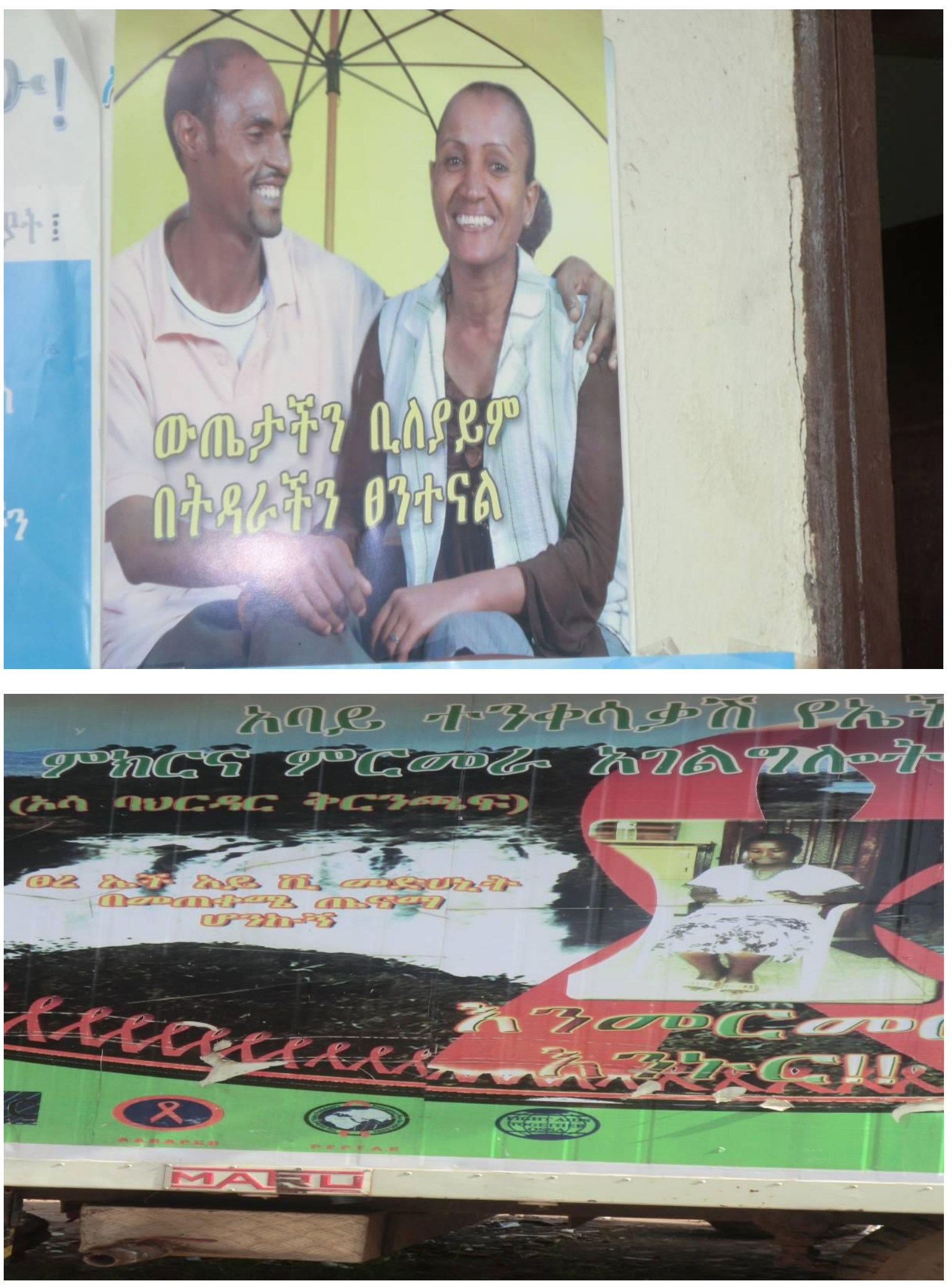


\section{$j\left(m_{T}\right.$}

Volume: 3 - Issue: 1 - January - 2013
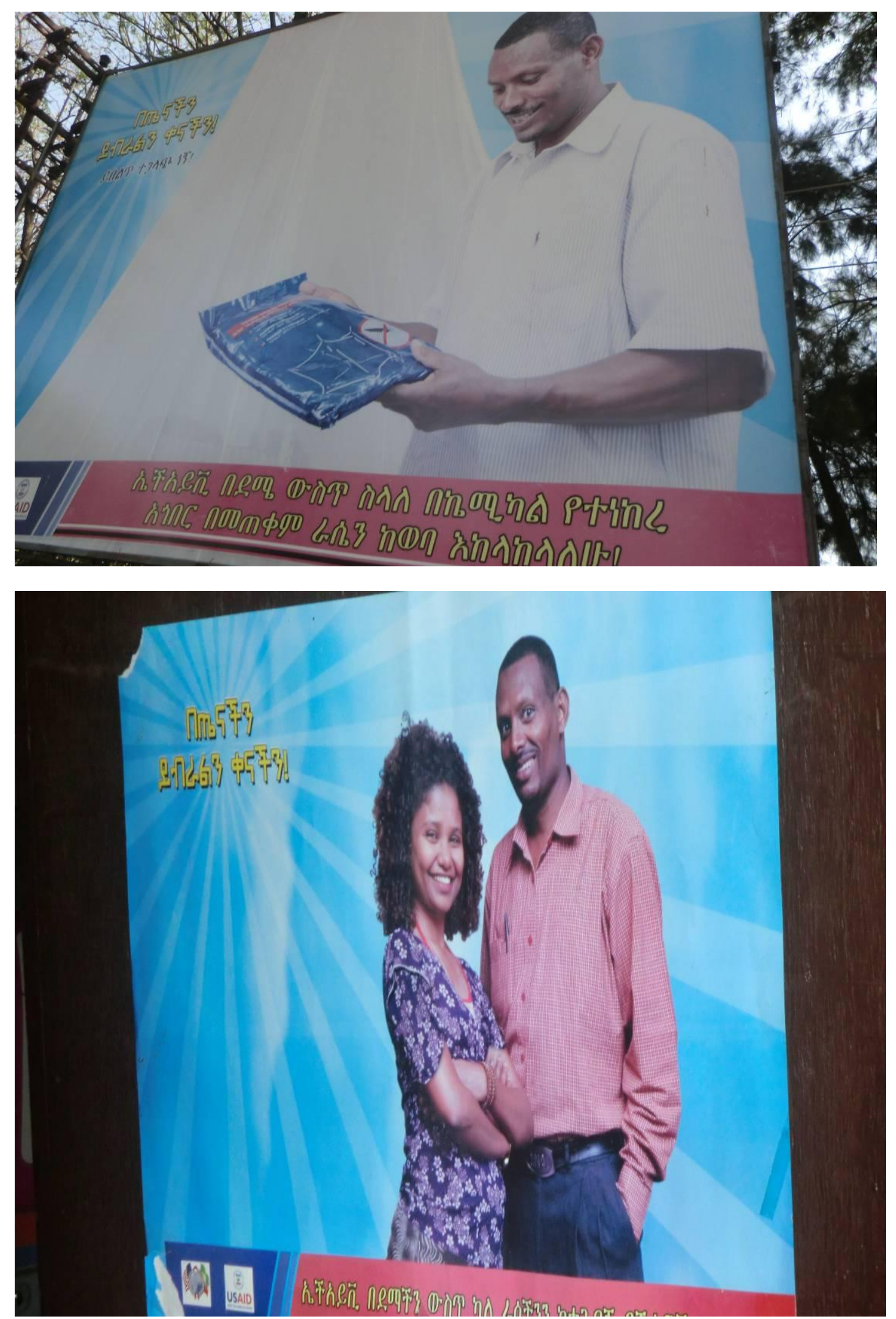
$j\left(m_{T}\right.$

Volume: 3 - Issue: 1 - January - 2013

Appendix E: A Billboard Depicting the Life of a Family before and after Blood Test for HIV

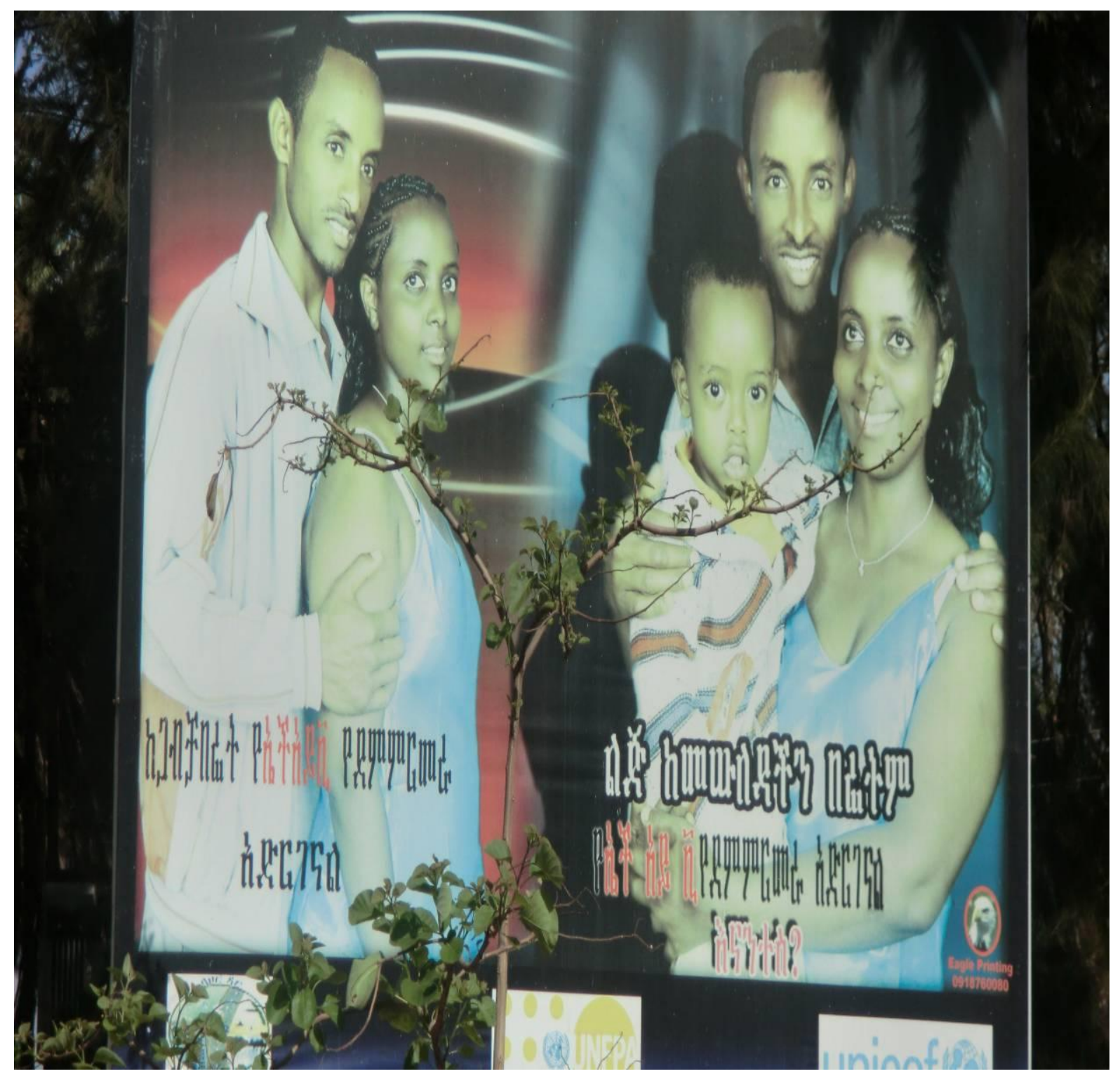


Appendix F: A Billboard Depicting How Difficult It Is to Identify People with HIV from others (Who Are Not) by Sight

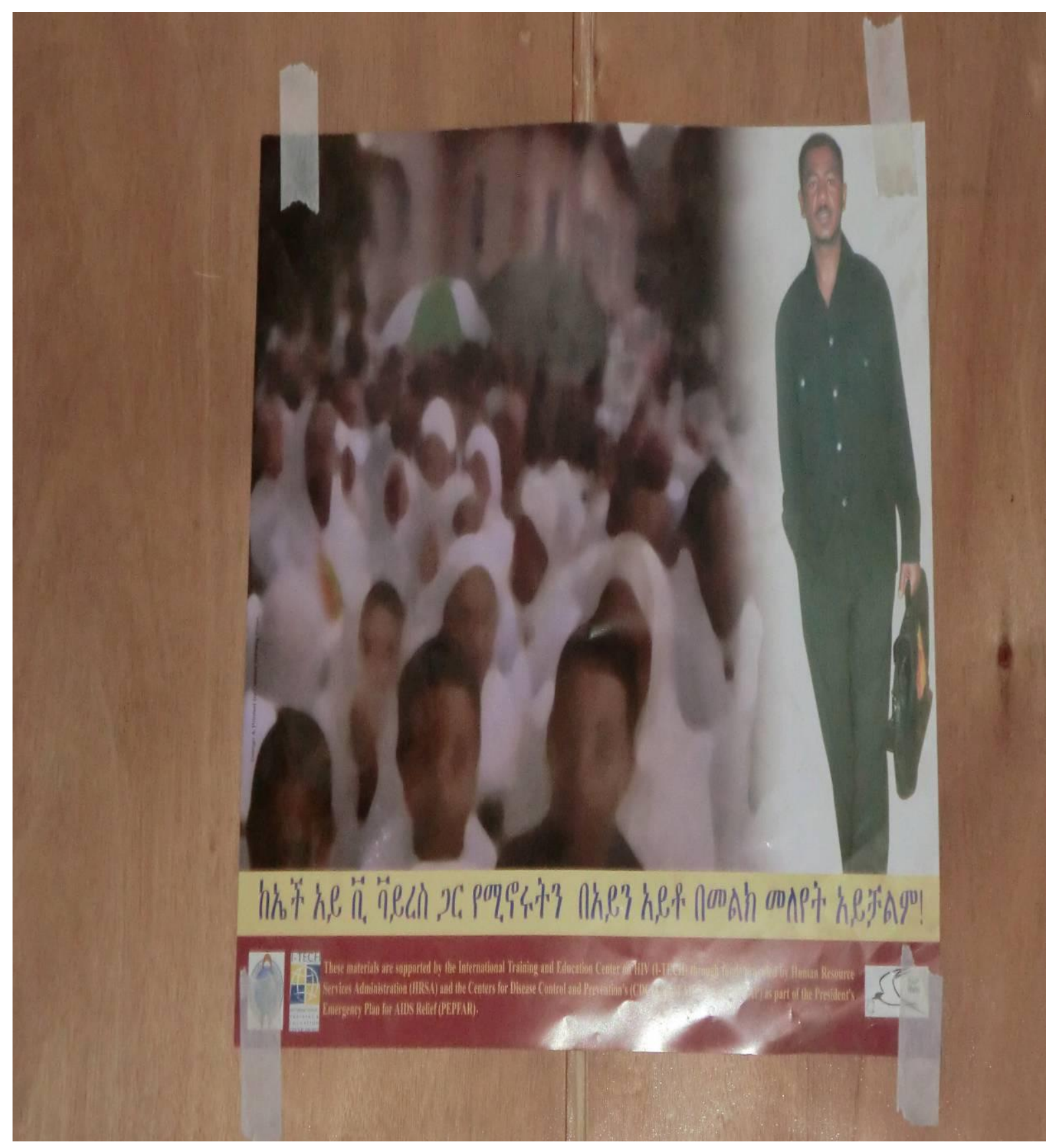


Appendix G: Billboards Showing the Goals of University Students and other Football Players.
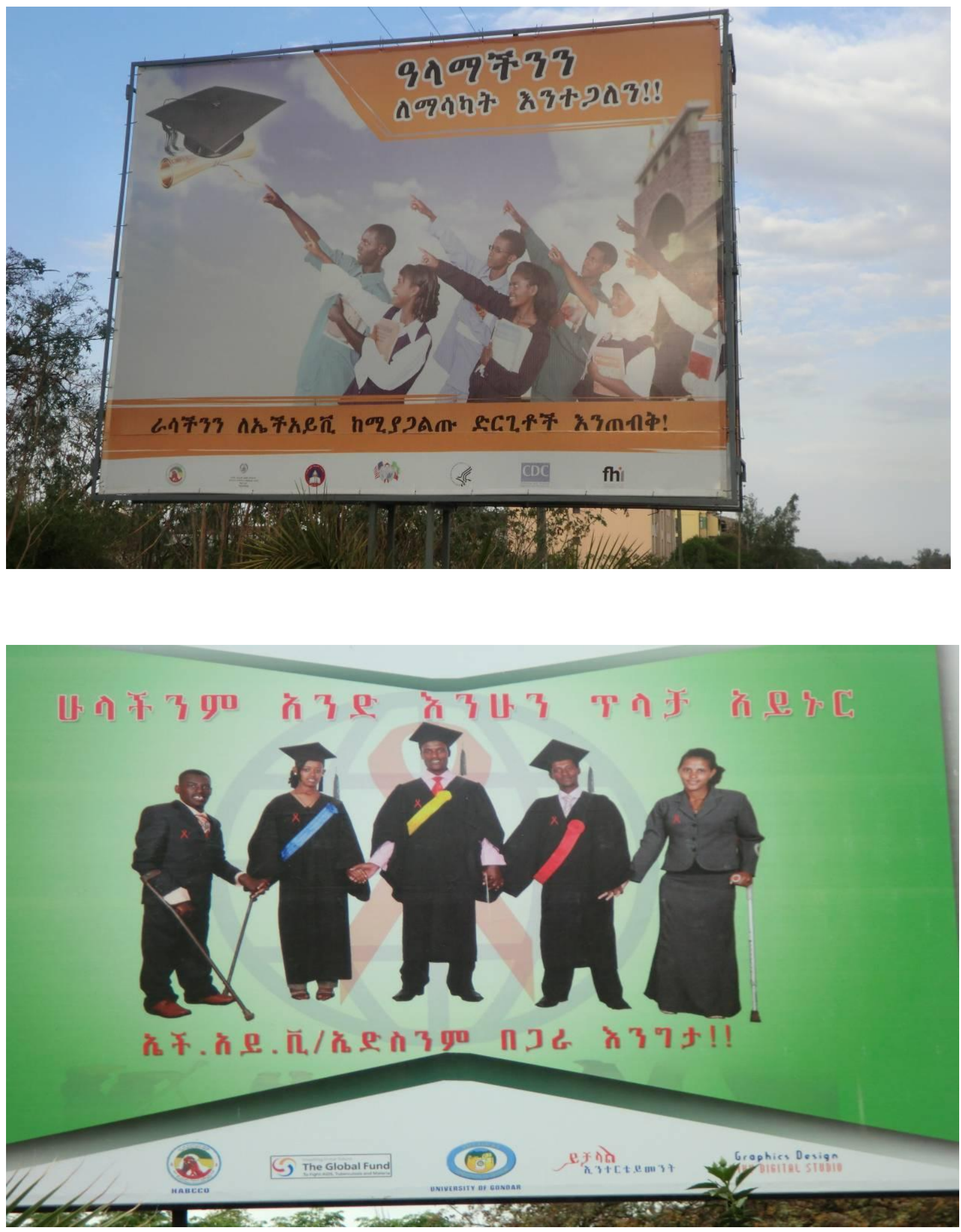


\section{j(m}

Online Journal of Communication and Media Technologies

Volume: 3 - Issue: 1 - January - 2013

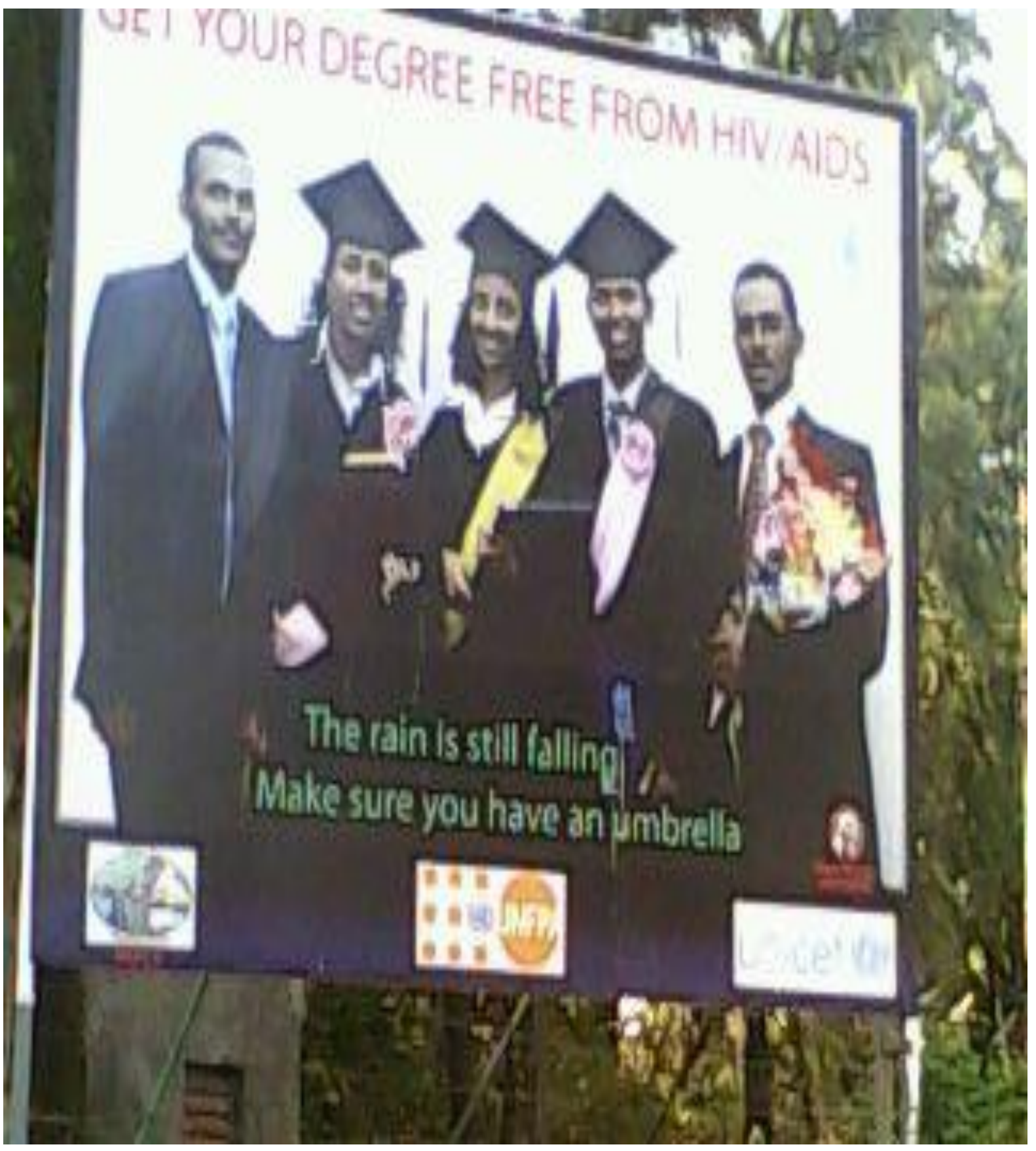


$\cdot\left(\mathrm{M}^{\mathrm{T}}\right.$

Volume: 3 - Issue: 1 - January - 2013
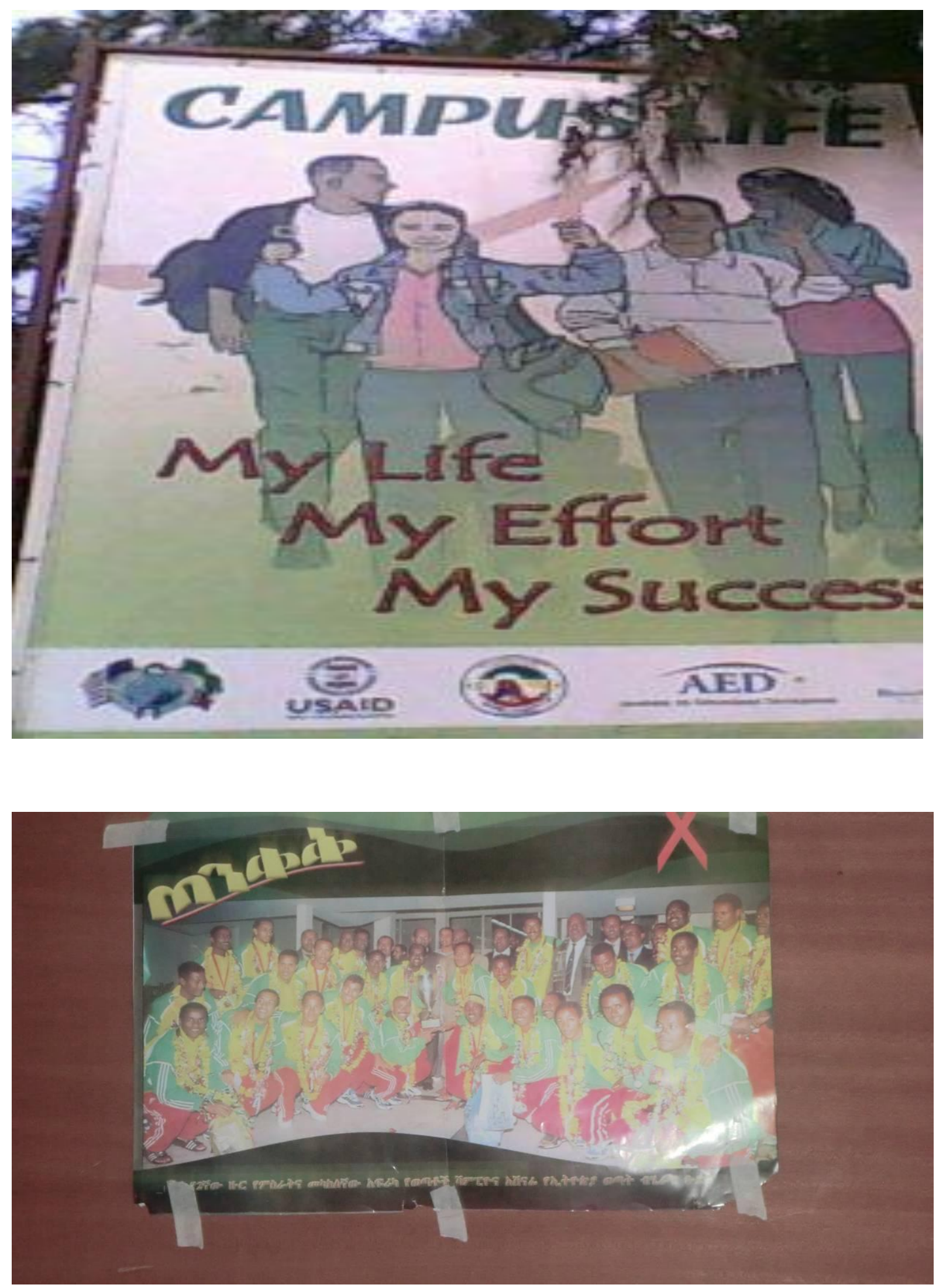

(c) Online Journal of Communication and Media Technologies 
$j\left(m_{T}\right.$

Appendix H: A Billboard Depicting the Wise Use of Condoms by Partners as a Way Forward to Civilized Society

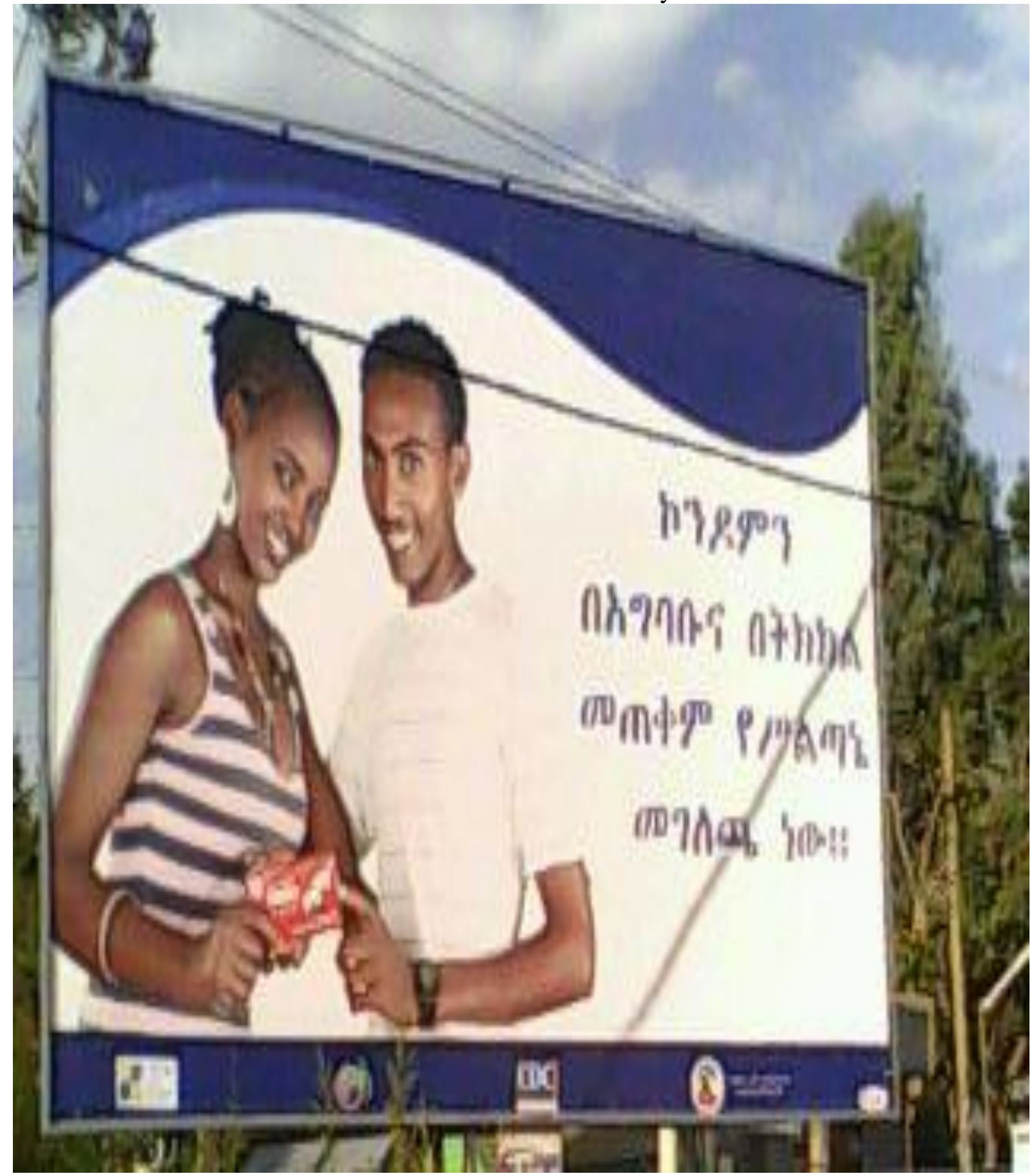


Appendix I: Billboards Dipicting Religious Leaders and Public Figures While Informing People about the HIV/AIDS

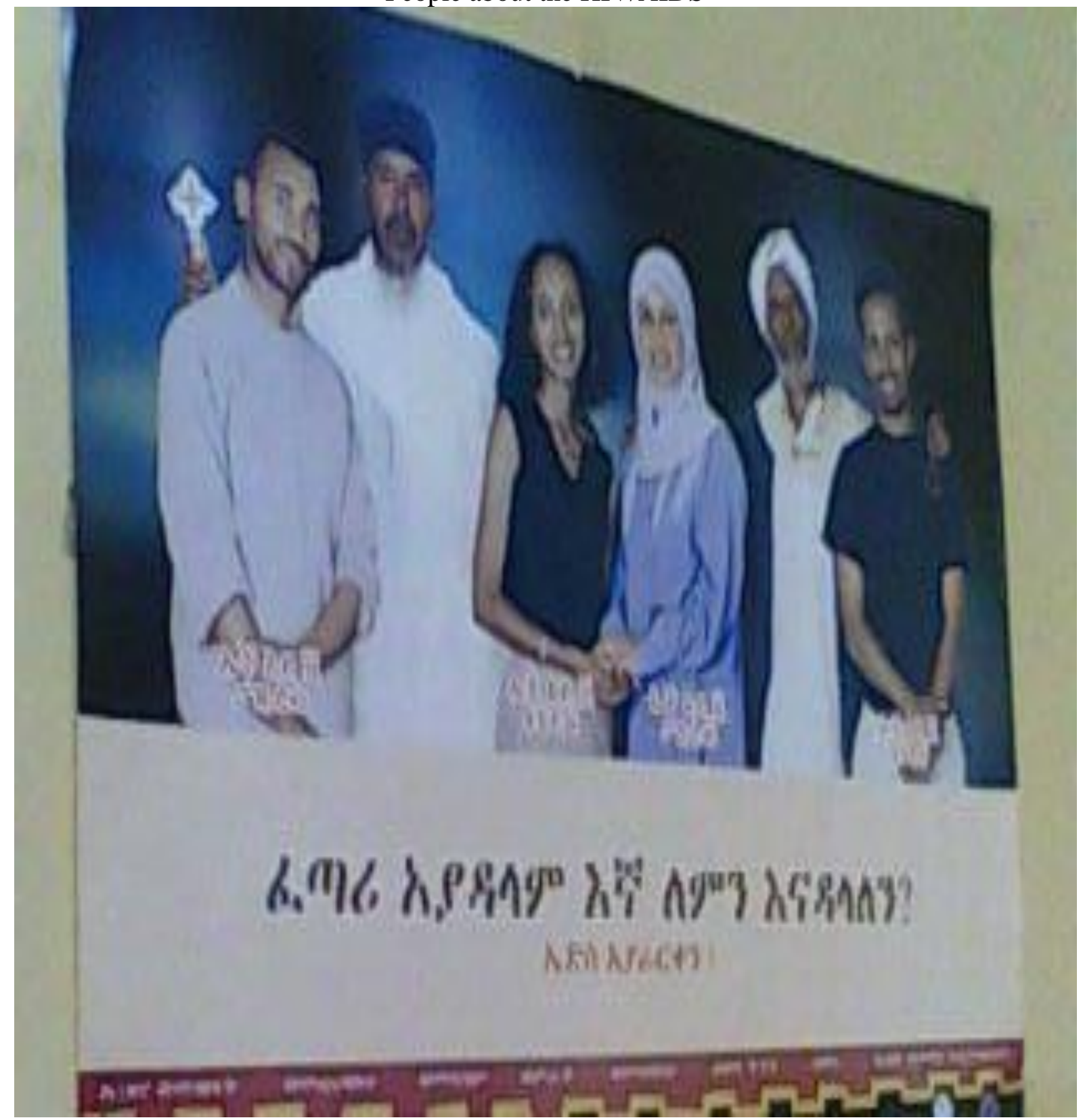


$j\left(m_{T}\right.$

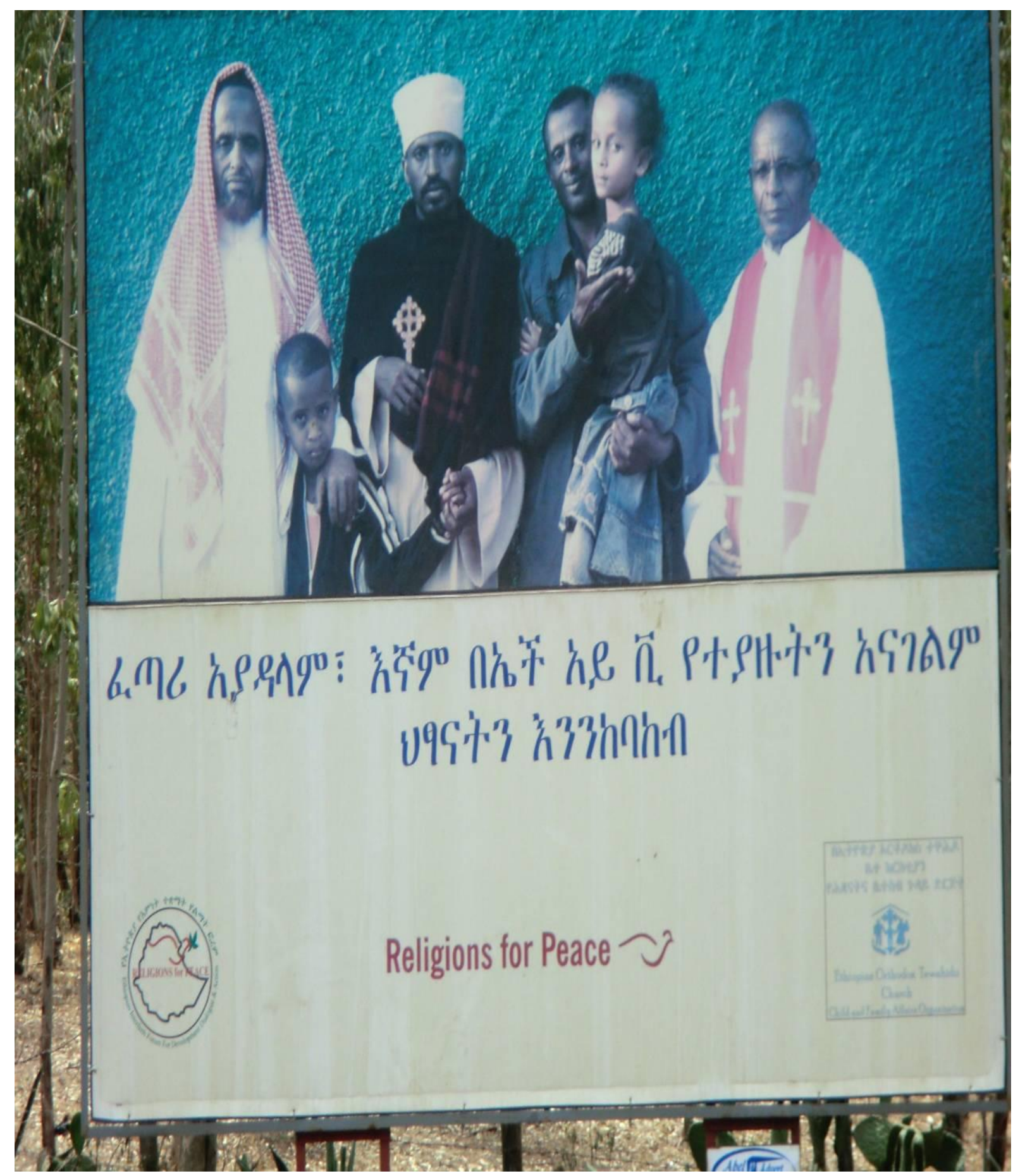

